DOI 10.15290/cnisk.2020.02.09.07

\begin{abstract}
ANNA SZWED-WALCZAK
https://orcid.org/0000-0002-9878-1401

Uniwersytet Marii Curie-Skłodowskiej w Lublinie

\section{Prasa jako narzędzie społecznej i politycznej aktywizacji kobiet w latach 1989-1992. Polska prasa dla kobiet w czasie transformacji ustrojowej ${ }^{1}$}

\title{
Streszczenie
}

Periodyki dla kobiet w Polsce w latach 1989-1992 stanowiły szczególny rodzaj prasy: $z$ jednej strony skierowane były do adresata dominujacego liczebnie $\mathrm{w}$ społeczeństwie, $z$ drugiej zaś strony będącego dyskryminowana mniejszością w sferze publicznej. Sytuację kobiet komplikował fakt prawnego równouprawnienia, które nie było realizowane w praktyce. Powyższe opinie znalazły odzwierciedlenie w badaniach. Wybrane do analizy tytuly prasowe: „Kobieta i Życie”, „Przyjaciółka”, „Zwierciadło” w ówczesnym okresie należały do najbardziej poczytnych czasopism w Polsce. Przemiany transformacyjne stanowiły dla nich okazję do promocji udziału kobiet w polityce, gospodarce i kulturze. Celem badania było ustalenie, czy prasa dla kobiet wykorzystała przemiany transformacyjne do aktywizacji społecznej i politycznej kobiet. W związku z tym sformułowano trzy pytania badawcze: 1) Jakie wydarzenia o charakterze politycznym wywołały zainteresowanie redakcji? 2) Jaką rolę dla kobiet dostrzegano w okresie przemian transformacyjnych? 3) W jaki sposób zachęcano kobiety do aktywność społecznej i politycznej?

Słowa kluczowe: „Kobieta i Życie”, „Przyjaciółka”, „Zwierciadło”, prasa dla kobiet, transformacja ustrojowa, 1989-1992

1 Publikacja przygotowana/finansowana w ramach programu Ministra Nauki i Szkolnictwa Wyższego pod nazwa DIALOG w latach 2019-2021. Jest wynikiem udziału w projekcie badawczym pt. „Ośrodek badań historii kobiet”, nr 0016/DLG/2019/10. 


\title{
PRESS AS A TOOL OF SOCIAL AND POLITICAL ACTIVATION OF WOMEN IN 1989-1992. POLISH PRESS FOR WOMEN DURING THE POLITICAL TRANSFORMATION
}

\begin{abstract}
The women's press in Poland in 1989-1992 was a special kind of press: on the one hand it was addressed to the addressee dominating in numbers in society, and on the other hand it was addressed to a discriminated minority in the public sphere. The situation of women was complicated by the fact of legal equality, which was not implemented in practice. The above opinions were reflected in the research. The press titles selected for analysis: Kobieta $i$ Życie [Woman and Life], Przyjaciółka [Best Friend], Zwierciadło [Mirror] at that time belonged to the most widely read magazines in Poland. Political transformation was an opportunity for women's press to promote women in politics, economy and culture. The aim of the study was to determine whether the women's press used transformations for social and political activation of women. Therefore three research questions were formulated: 1) What political events were written in the women's press? 2) What role for women was seen during the transformation period? 3) How were women encouraged to social and political activities?

Keywords: Kobieta i Życie [Women and Life], Przyjaciółka [Best Friend], Zwierciadło [Mirror], political transformation, women's press in Poland, 1989-1992

\section{Wstęp}

Przemiany systemu politycznego Polski zapoczątkowane w 1989 r. skutkowały też transformacją systemu medialnego. W trakcie obrad Okragłego Stołu działał podzespół do spraw masowego przekazu, który postulował pluralizm mediów, zniesienie monopolu prasy i jej prywatyzację (likwidację koncernu RSW „Prasa-Książka-Ruch”2, co nastąpiło

2 Został on zainicjowany w 1973 r. i stał się monopolistą w zakresie kolportażu prasy w Polsce. Jak wskazują badacze, koncern Robotnicza Spółdzielnia Wydawnicza „PrasaKsiążka-Ruch" był największym przedsiębiorstwem prasowo-poligraficzno-kolportażowym w Europie. Jego budowę rozpoczęto po II wojnie światowej, kiedy to w kwietniu 1947 r. Sekretariat Komitetu Centralnego Polskiej Partii Robotniczej uchwała powołał Robotniczą Spółdzielnię Wydawniczą „Prasa”, która wraz z rozbudową zaczęła wchłaniać pozostałe wydawnictwa, co udało się osiagnąc w 1951 r. Vide: Wiktor Pepliński, „350 lat historii prasy w Polsce (spojrzenie na jej przeszłość i teraźniejszość)", Studia Medioznawcze, nr 2,
\end{abstract}


w efekcie wejścia w życie ustawy z 22 marca 1990 r. o likwidacji Robotniczej Spółdzielni Wydawniczej „Prasa-Książka-Ruch”) oraz derogacji cenzury (likwidacja ustawą z 11 kwietnia 1990 r. Głównego Urzędu Kontroli Prasy, Publikacji i Widowisk) ${ }^{3}$. Czasopisma zgromadzone dotychczas w koncernie stanęly przed wyzwaniem utrzymania się na rynku prasowym (zmiana formy funkcjonowania na spółdzielcza, budowa prywatnych wydawnictw, wykup przez zagraniczne koncerny) bez wsparcia finansowego i mecenatu państwa ${ }^{4}$. Znalazły się wśród nich wydawnictwa dysponujace czasopismami dla kobiet: Warszawskie Wydawnictwo Prasowe, Wydawnictwo Współczesne, Polska Agencja „Interpress”, Oficyna Wydawnicza „Wiedza i Życie”. Kwestia ich przetrwania nie stanowiła jednak głównego punktu rozważań redakcji. Poza rosnacymi cenami (czasem o 70\%), problemami $z$ dostarczeniem prenumeraty („Kobieta i Życie”, „Przyjaciółka” i „Magazyn Rodzinny”) czytelnik prasy dla kobiet nie dostrzegał dezorganizacji pracy redakcji. Wręcz przeciwnie, zauważalny był dla niego rozwój tego sektora prasy - jeszcze w 1989 r. ${ }^{6}$ pojawiały się nowe tytuły, np. magazyn „Ewa” czy kwartalnik „Pani” oraz dodatki

2011, 34; Wiesław Sonczyk, „Kolportaż prasy w Polsce do roku 1989”, Studia Medioznawcze, nr 2, 2010, 81-83.

3 Zofia Sokól, „Transformacja czasopism kobiecych w Polsce (1989-1997)”, Rocznik Historii Prasy Polskiej, z. 2, 1998, 193.

4 Lucyna Szot zauważyła, że koszty społeczne transformacji mediów w Polsce ponieśli dziennikarze. Po pierwsze zdezawuowano ich zawód, po drugie wielu z nich straciło pracę. Jak wskazała badaczka, Komisja Likwidacyjna RSW, spełniając potrzebę społeczna dotycząca „politycznej sanacji polskiej prasy”, nie dała jej szans rozwoju w momencie wkraczania na rynek międzynarodowej konkurencji. Skutkowało to wykupem prasy przez zagraniczne koncerny lub upadkiem redakcji zmagającej się $z$ konkurencją czasopism niemieckich, Lucyna Szot, „Wpływ profesjonalizmu dziennikarzy na transformację polskiej prasy po 1989 roku", Studia Medioznawcze, nr 2, 2010, 27. Jako pierwsze na polskim rynku pojawiły się wydawnictwa niemieckie „Burda Polska” w 1990 r. oraz w 1991 r. H. Bauer, vide szerzej: Olga Dąbrowska-Cendrowska, „Dwadzieścia lat minęło. Działalność wydawnicza koncernów: Burda Polska, H. Bauer, Gruner+Jahr Polska i Axel Springer Polska na polskim rynku prasowym", Studia Medioznawcze, nr 2, 2010, 91, 94; Jerzy Jarowiecki, Studia nad prasa polska XIX i XX wieku, (Kraków : Wydawnictwo Naukowe WSP, 1997), 202-208.

5 W świetle Uchwały nr 172 (poz. 13) Rady Ministrów z dnia 29 października 1990 w sprawie zatwierdzenia planu zagospodarowania majątku Robotniczej Spółdzielczej Wydawniczej „Prasa - Ksiażka - Ruch” w likwidacji oraz w sprawie dysponowania składnikiem majątku tej Spółdzielni wskazano, że pisma dla kobiet wychodzące we wskazanych wydawnictwach zostały przekazane spółdzielniom pracy.

6 Tomasz Mielczarek wyliczył, że w 1990 r. założono 14 pism dla kobiet, rok później - 37, a w 1992 r. 17, vide: Tomasz Mielczarek, „Pożegnanie z prasą. Czy w Polsce kończy się era Gutenberga?”, Zeszyty Prasoznawcze, nr 1-2, 2007, 56; idem, „Współczesne polskie czasopisma wysokonakładowe", Rocznik Prasoznawczy, R. II, 2008, 59. 
do już istniejących ${ }^{7}$. Coraz częściej i odważniej podejmowano rozważania o oczekiwanych zmianach politycznych, oceniano je, prognozowano dalsze działania rządu i opozycji, ale też proponowano konkretne rozwiązania problemów społecznych i politycznych. Cezura początkowa badań związana była więc $z$ zainicjowaniem transformacji politycznej i zmiana systemu medialnego w Polsce, zaś cezura końcowa badań uzasadniona była czterema czynnikami: 1) zakończeniem przemian własnościowych prasy, 2) zamknięciem pism „Ewa” oraz „Magazyn Rodzinny”, 3) rozwojem tytułów prasowych $\mathrm{z}$ zagranicznym kapitałem na polskim rynku prasowym (od 1990 r. „Twój Styl”, „Burda”, „Tina”), 4) uchwaleniem tzw. Małej Konstytucji ${ }^{8}$.

Przedmiotem badań były pisma dla kobiet o ugruntowanej pozycji rynkowej pod koniec lat 80. XX w.: „Przyjaciółka”, „Kobieta i Życie”, „Zwierciadło". Wskazane czasopisma u progu transformacji miały już dość długie doświadczenie. Pismo „Przyjaciółka” na polskim rynku funkcjonowało od 1948 r. Charakteryzowało się mocna więzią z czytelnikami, co przejawiało się rozbudowaną rubryką $z$ listami. Skierowane było do kobiet wiejskich, chociaż w latach 1952-1975 wydawano mutację tygodnika przeznaczona dla kobiet miejskich, tym samym rozszerzając grupę odbiorców. Już w latach 50. XX w. nakład tygodnika przekroczył $2 \mathrm{mln}$ egzemplarzy, deklasujacc inne czasopisma. Przez kilka lat na łamach pisma pojawiały się rubryki informujące o działalności Ligi Kobiet oraz Koła Gospodyń Wiejskich. „Przyjaciółka” nie unikała wątków politycznych. Tygodnik „Kobieta i Życie” pojawił się w 1953 r. jako efekt fuzji pism

\footnotetext{
7 Zofia Sokół, „Transformacja czasopism”, 196-197, 199.

8 Badacze mediów dzielili ten okres na dwie fazy: V 1989 - 1. poł. 1991 r. oraz 2. poł. 1991 r. - XII 1992 r. Pierwsza faza związana była z koniecznościa zmian w dotychczas ukazujących się tytułach, nastapił też rozwój nowych pism. Druga fazę z kolei określono mianem „pozornej stabilizacji i zmian podskórnych w prasie i radiu”, Zbigniew Bajka, „Rynek mediów w Polsce”, w: Zbigniew Bauer, Edward Chudziński (red.), Dziennikarstwo $i$ świat mediów (Kraków : Universitas, 2004), 86.

9 Zofia Sokół, „Przyjaciółka» - tygodnik kobiecy. (Część II: marzec 1951 - marzec 1990)”, Studia Bibliologiczne Akademii Świętokrzyskiej, t. 7, 2003, 111; Vide szerzej: Justyna Zajko-Czochańska, „Monografia "Przyjaciółki" - zarys zagadnienia”, Niepodległość i Pamięć, nr 2, 2019, 213-226. Antonina Kłoskowska wskazała, że liczba czytelników „Przyjaciółki” była o wiele wyższa. Było to pismo łatwe w odbiorze, powszechnie dostępne i tanie względem konkurencyjnych tytułów, stąd jego odbiór nie ograniczał się wyłącznie do terenów wiejskich. Na przykład w latach 1950-1957 wydawcy zakładali, że każdy egzemplarz czytaja co najmniej trzy osoby, co w rezultacie podniosło liczbę czytelników do $6 \mathrm{mln}$, Antonina Kłoskowska, „Modele społeczne i kultura masowa”, Przeglad Socjologiczny, nr 13(2), 1959, 57-58.
} 
„Moda i Życie Praktyczne” (wychodzace od 1946 r. pierwsze powojenne pismo wydawane dla kobiet) oraz „Kobieta”. Czasopismo było skierowane do czytelniczek z miast, majacych aspiracje zawodowe, pracujących raczej umysłowo niż fizycznie, o średnim lub wyższym wykształceniu. Jednakże to nie oznacza, że „Kobieta i Życie” nie była czytana na obszarach wiejskich. W piśmie szeroko omawiano sprawy społeczne i polityczne. W jego redakcji znalazły się działaczki Ligi Kobiet Polskich ${ }^{10}$. Podobnie „Zwierciadło" (wychodzące od 1957 r.) współpracowało z Liga, a w latach 19821990 było organem prasowym Ligi Kobiet Polskich. Pismo przeznaczono dla czytelniczek $z$ wyższym wykształceniem lub w trakcie jego realizacji, niezależnych, dbających o własny rozwój intelektualny i zawodowy, aspirujących do aktywności społecznej i politycznej. Magazyn miał wymiar opiniotwórczy, szeroko prezentował działalność organizacji kobiecej ${ }^{11}$.

Wyniki badań Sylwestra Dzikiego potwierdziły, że wskazane tytuły prasowe w latach 1990-1991 utrzymały swoja pozycję, mimo że zmniejszył się ich nakład i wzrosła liczba konkurentów ${ }^{12}$. „Przyjaciółka” oraz „Kobieta i Życie” należały też do najpopularniejszych tygodników i dwutygodników w latach 1989-1992. „Przyjaciółka” zajmowała pierwsze miejsce we wskazanym okresie badawczym, „Kobieta i Życie” zaś drugie (poza rokiem 1990, kiedy to wyprzedziła ją „Polityka”). „Zwierciadło” w latach 1989-199013 znalazło się na piątym miejscu, choć w 1990 r. zauważalny jest spadek zainteresowania pismem (w 1991 r. nastapił wzrost jego sprzedaży $)^{14}$.

Celem badań było ustalenie, czy prasa dla kobiet wykorzystała przemiany transformacyjne do aktywizacji społecznej i politycznej kobiet. W zwiąku z tym sformułowano trzy pytania badawcze: 1) Jakie wydarzenia

10 Zofia Sokół, „Wizerunki kobiet na łamach tygodnika "Kobieta i Życie» w latach 19462002”, Rocznik Prasoznawczy, R. VI, 2012, 12; Małgorzata Hajdo, „Wizerunek kobiety jako matki, pracownika i działaczki społecznej prezentowany na łamach prasy kobiecej w latach 1948-1956", Dzieje Najnowsze, R. XXXVIII, 2006, 56.

11 Małgorzata Dajnowicz, „Posłanki Ligi Kobiet Polskich i wybory parlamentarne 1989 roku (prezentacja w świetle „Zwierciadła”), w: Małgorzata Dajnowicz, Adam Miodowski (red.), Polityka i politycy $w$ prasie XX i XXI wieku: polityka w prasie kobiecej, (Białystok : Wydawnictwo Uniwersytetu w Białymstoku, 2019), 206-207; eadem, "Zwierciadło" platforma polityczna Ligi Kobiet w okresie PRL (1957-1961, 1982-1989)", Rocznik Historii Prasy Polskiej, t. 3, 2017, 72-74.

12 Sylwester Dziki, „Zmiany oferty prasowo-wydawniczej (1990-1991)”, Zeszyty Prasoznawcze, nr 3-4, 1991, 26.

13 Od XII 1990 r. zmieniła się częstotliwość wydawania pisma $z$ tygodnika na miesięcznik. 14 Ryszard Filas, „Zmiany poczytności gazet i czasopism o zasięgu ogólnopolskim (19891992)", Zeszyty Prasoznawcze, nr 1-2, 1992, 61-62. 
o charakterze politycznym wywołały zainteresowanie redakcji? 2) Jaką rolę dla kobiet dostrzegano w okresie przemian transformacyjnych? 3) W jaki sposób zachęcano kobiety do aktywności społecznej i politycznej?

W pracy wykorzystano ilościową i jakościową analizę zawartości prasy ${ }^{15}$. Przebadano wszystkie numery pism, które zostały wydane w latach 1989-1992. Z szerokiej oferty tematycznej poruszanej na łamach badanej prasy dla kobiet (tj. moda, uroda, zdrowie, kulinaria, poradnictwo, rozrywka, życie codzienne, społeczeństwo, polityka, gospodarka) wyszczególniono teksty dotyczacce aktywności społecznej i politycznej kobiet jako grupy interesu, ich udziału w zmianie życia politycznego w Polsce oraz roli w nowym ustroju politycznym. Pod uwagę wzięto materiały, które informowały czytelników o przemianach ustrojowych, powstajacych organizacjach kobiecych, formach aktywności kobiet, prawach i obowiazkach kobiet w nowym systemie politycznym. Określona tematyka miała bezpośrednie przełożenie na budowanie tożsamości kobiet jako obywatelek $^{16}$. Najwięcej materiałów w tej tematyce w badanym okresie pojawiło się na łamach „Kobiety i Życia”, zob. tabela 1.

Tabela 1. Liczba wyselekcjonowanych materiałów prasowych $z$ uwzględnieniem podziału na czasopismo

\begin{tabular}{|c|c|c|c|}
\hline Rok publikacji & „Kobieta i Życie” & „Przyjaciółka” & „Zwierciadło" \\
\hline 1989 & 77 & 56 & 71 \\
\hline 1990 & 34 & 23 & 25 \\
\hline 1991 & 39 & 33 & 6 \\
\hline 1992 & 49 & 15 & 2 \\
\hline W sumie: & 199 & 127 & 104 \\
\hline
\end{tabular}

Źródło: opracowanie własne.

Należy zaznaczyć, że materiały na ten temat w „Przyjaciółce” oraz „Zwierciadle" zaczęły rzadziej pojawiać po wyborach kontraktowych (VI 1989 r.), aczkolwiek w tygodniku „Przyjaciółka” wzrosła ich liczba w roku wolnych wyborów parlamentarnych w 1991 r., by zmniejszyć się o ponad połowę w roku 1992. Związane było to $z$ kampanią wyborcza, w której promowano akcję oddawania głosu na kobiety. Podobna

15 Vide szerzej: Walery Pisarek, O mediach i języku, (Kraków : Universitas, 2007), 53-62.

16 Jonathan Bignell, Media Semiotics. An Introduction, (Manchester : Manchester University Press, 2002), 59-61. 
tendencja w latach 1990-1991 pojawiła się w „Kobiecie i Życiu”, z tą jednak różnica, że po spadku liczby artykułów na temat społecznej i politycznej aktywizacji kobiet w 1990 r. od 1991 r. nastapił wzrost materiałów dotyczących tej problematyki. Związane to było $z$ zaangażowaniem się redakcji w protest przeciwko projektowi ustawy o prawnej ochronie dziecka poczętego i w promowanie działalności Koła Parlamentarnego Kobiet.

\section{Wydarzenia polityczne nagłaśniane w prasie dla kobiet}

W latach 1989-1992 szczególne zainteresowanie redakcji badanych pism wzbudził projekt ustawy o prawnej ochronie dziecka poczętego, który został wniesiony 28 lutego 1989 r. do laski marszałkowskiej przez Koło Poselskie Zwiąku Katolicko-Społecznego. Jego celem było zniesienie Ustawy z dnia 27 kwietnia 1956 r. o warunkach dopuszczalności przerywania ciaży ${ }^{17}$. Projekt całkowicie zakazywał aborcji, przewidując za nią kary więzienia zarówno dla osoby poddającej się zabiegowi, jak i dla osoby go wykonujacej ${ }^{18}$. Temat projektu ustawy penalizujaccej aborcję zdominował dyskurs w latach 1989-1992. Anna Frankowska wskazała, że „kiedy pojawiła się dyskusja o penalizacji aborcji, ludzie myśleli że "czerwoni" chcą odwrócić uwagę społeczeństwa od istotnych zmian społecznych. Obecnie nowa władza wraca do starej koncepcji, a na posiedzenie komisji senackiej 10 IV [1990 r.] nie wpuściła przedstawicielek organizacji kobiecych i prasy"19.

Sprawę projektu ustawy o prawnej ochronie dziecka poczętego klasyfikowano do kwestii politycznych. Działania zmierzajace do wycofania projektu ustawy określano „batalią o godność i odpowiedzialność”.

\footnotetext{
17 Zgodnie $z$ ustawą zabieg mógł przeprowadzić lekarz, tylko kiedy przemawiały za tym względy medyczne, trudne warunki życiowe kobiety, ciąża powstała w wyniku przestępstwa, Ustawa $z$ dnia 27 kwietnia 1956 r. o warunkach dopuszczalności przerywania ciązy, Dz. U. z 1956 r., nr 12, poz. 61.

18 Wywiad Małgorzaty Bińkowskiej z Wandą Bogusławska: „Wywiad na zamówienie: Pigułka czy spirala?”, Kobieta i Życie [dalej: KiŻ], nr 1, 4.01.1989, 17; „Źle strzeżona brama”, KiŻ, nr 14, 5.04.1989, 5; Irma Wieczorkowska-Bednarek, „Prosto z Sejmu: "Gdy dwoje mówi to samo", $K i \dot{Z}, \mathrm{nr} 11$, 14.03.1990, 11; Anna Frankowska, „Brzemienne paragrafy”, KiŻ, nr 32, 8.08.1990, 4-5; Zofia Zubczewska, „Kto co mówi”, KiŻ, nr 16, 17.04.1991, 5; Rozmowa Marii Mankiewicz z Anną Popowicz: „Dywan z małych kawałków”, Kì̇, nr 18, 1.05.1991, 5; Janina Ratyńska, „Kara czy sumienie”, Przyjaciótka [dalej: Prz], nr 15, 13.04.1989, 7; Krystyna Kurczab-Redlich, „Ostatnia furtka”, Prz, nr 18, 4.05.1989, 6.

19 Anna Frankowska, „Powrót do szaleństwa”, KiŻ, nr 23, 6.06.1990, 2.
} 
Projekt oceniono jako godzący w prawa człowieka. Wskazano, że może on doprowadzić do reaktywacji podziemia aborcyjnego, powrotu do czasów usuwania płodu szydełkiem, a w konsekwencji śmierci wielu kobiet ${ }^{20}$. Intensyfikacja tematyki penalizacji aborcji miała miejsce przed wyborami kontraktowymi w 1989 r. oraz przed pierwszymi wolnymi wyborami w 1991 r. Przejawiało się to w artykułach, wywiadach, oświadczeniach, ale też w listach od czytelników, w których opowiadano się za lub przeciw projektowi ustawy. Dominowały listy negujacce propozycję penalizacji aborcji $^{21}$, co było zbieżne ze stanowiskami redakcji badanych pism ${ }^{22}$.

${ }^{20}$ Ibidem. Vide również: Iwona Konarska, „Życie poczęte chronić mają paragrafy. Na nic więcej nas nie stać. Czy to etyczne?”, Kï̇, nr 22, 27.05.1992, 2; „Stanowisko Ligi Kobiet Polskich w sprawie dopuszczalności przerywania ciaży”, Zwierciadło [dalej: $Z w$ ], nr 18, 4.05.1989, 4-5; Elżbieta Wierzbicka, „Między sumieniem a więzieniem”, $Z w$, nr 26, 29.06.1989, 3.

21 W „Kobiecie i Życiu” były to rubryki: 1. „Ludzie listy pisza”, np. „Zabieg”, Ki̇̇, nr 4, 25.01.1989,10-11; „Zabieg (2)”, Ki்̇, nr 14, 5.04.1989, 10-11; „Piekło kobiet”, KiŻ, nr 44, 31.10.1990, 10-11; „Zejdźmy na ziemię”, KiŻ, nr 17, 24.04.1991, 10-11; „Nad listami: Sterylizacja?”, KiŻ, nr 29, 18.07.1990, 11; 2. Wywiady, np. wywiad Elżbiety Wierzbickiej z Aliną Koźnińską: „Pro life”, KiŻ, nr 3, 16.01.1991, 4-5; wywiad Kaliny Gawęckiej z Anną Mieszczanek: „Neutrum”, Ki்̇, nr 3, 16.01.1991, 5; 3. Bieżące tematy: Danuta Bierzańska, „Ponad głowami”, KiŻ, nr 18, 2.05.1990, 4-5; Elżbieta Wierzbicka, „Więcej niż dwie strony”, Kï், nr 8, 20.02.1991, 5; Zofia Zubczewska, „Konsultacja”, KiŻ, nr 11, 13.03.1991, 3; eadem, „...A natura wie swoje”, Ki்̇, nr 21, 22.05.1991, 2; eadem, „Zamiast wywiadu na zamówienie: "Lęki i żale", KiŻ, nr 18, 29.04.1992, 23; Iwona Konarska, „Ciemności kryją kodeks”, Ki்̇, 29.01.1992, nr 5, 2; eadem, „Niemoralna”, Ki்̇, nr 31, 29.07.1992, 2. W „Przyjaciółce” stworzono rubrykę „Bardzo "goracy" temat”, gdzie zamieszczano listy, ale też artykuły na temat projektu, np. Prz, nr 9, 28.02.1991, 6; Prz, nr 10, 7.03.1991, 6; Prz, nr 11, 14.03.1991, 4-5; Prz, nr 12, 21.03.1991, 4-5. Materiały pojawiały się również poza rubryka, np. „Wasze listy”: „W sprawie przerywania ciąży”, Prz, nr 19, 11.05.1989, 7; K.K-R., „Bolesna sprawa”, Prz, nr 23, 8.06.1989, 7; „Wokół projektu ustawy o ochronie życia poczętego: "Za i przeciw»", Prz, nr 32, 9.08.1990, 6; „Oświadczenie w sprawie projektu ustawy o ochronie prawnej dziecka poczętego”, Prz, nr 43, 25.10.1990, 5; rozmowa Zygmunta Włoczewskiego z Małgorzatą Kielską-Żukowską: „Chcemy się rządzić sami”, Prz, nr 16, 19.04.1990, 5. W „Zwierciadle” wypowiedzi na temat projektu ustawy zamieszczano głównie w dwóch działach: 1. „Za i przeciw ustawie...”, np. Zw, nr 18, 4.05.1989, 4-5; $Z w, \mathrm{nr} 19,11.05 .1989,2 ; Z w, \mathrm{nr} 20,18.05 .1989$, 6; oraz 2. „Chcemy o tym decydować”, np. $Z w$, nr 21, 25.05.1989, 4-5; $Z w$, nr 22, 1.06.1989, 4-5; $Z w$, nr 24, 15.06.1989, 4-5; $Z w, \mathrm{nr} 28,13.07 .1989,11 ; Z w, \mathrm{nr} 34,7.09 .1989$, 4. Podobnie jak w pozostałych tytułach pojawiały się też materiały poza rubrykami, jak np. „Oświadczenie”, Zw, nr 43, 9.09.1989, 5; „Stanowisko niezależnych ruchów kobiecych”, Zw, nr 20, 17.05.1990, 7; E.W., „Zamach na tolerancję”, $Z w, \mathrm{nr} 23,7.06 .1990,8-9$; „Zamach na tolerancję", $Z w, \mathrm{nr} 25,21.06 .1990$, 2-3; „Nasze oczekiwania”, Zw, nr 12, 23.03.1989, 11.

${ }^{22} \mathrm{~W}$ jednym $z$ listów zarzucono redakcji „Przyjaciółki” nieobiektywizm w prezentacji stanowisk względem projektu. „Wasze listy”: „W sprawie ostatniej furtki”, Prz, nr 24, 15.06.1989, 7. W odpowiedzi redakcja wydrukowała projekt nowej ustawy oraz ustawę z 1956 r., wskazując, że czytelnicy sami powinni wyrobić sobie zdanie w tej kwestii, vide więcej: „Ty musisz wiedzieć, by mieć własne zdanie”, Prz, nr 25, 22.06.1989, 6-7, 
Deklarowały one, że nie popieraja i nie promuja aborcji, lecz postuluja za moralnym wyborem kobiety. Wielokrotnie podkreślano, że aborcja jest „złem ostatecznym”23. Porównywano sytuację wokół ustawy z ustawodawstwem II RP, kiedy to w 1932 r. w Kodeksie Karnym znalazł się zapis o karaniu więzieniem kobiety i wykonawcy aborcji ${ }^{24}$. W toku debat nad ustawą ostatecznie zrezygnowano $z$ karania kobiety oraz służby medycznej za przerywanie ciąży w przypadku zagrożenia dla zdrowia i życia kobiety oraz kiedy ciaża była wynikiem przestępstwa ${ }^{25}$.

Na łamach prasy dla kobiet za doniosłe i przełomowe wydarzenie polityczne uznano obrady Okragłego Stołu. Zarówno w „Kobiecie i Życiu”, jak i w „Przyjaciółce” opublikowano wywiad z profesor Anną Przecławska, jedyna kobieta obecna na inauguracji wydarzenia ${ }^{26}$. Niepokój redakcji wzbudziła niereprezentatywność kobiet w trakcie inauguracji obrad Okragłego Stołu oraz brak podstolika zajmującego się chociażby warunkami pracy kobiet w przemyśle ${ }^{27}$. Jednakże, mimo niezabezpieczenia praw kobiet w czasie obrad, redakcje prasy dla kobiet doceniły inicjatywę spotkania koalicji rządzącej z opozycją solidarnościową. Obrady ukazywano jako „preludium do reform”28. W „Zwierciadle” zastanawiano się, jakie będą ich efekty ${ }^{29}$. W „Przyjaciółce” ostrzegano, że na pozytywne skutki przemian społecznych i politycznych trzeba będzie poczekać. Wiesława Piątek pisała: „Okragły Stół to nie czarodziejska różdżka, która

następnie opublikowano wywiad z ginekologiem-położnikiem, który wskazał konsekwencje psychosomatyczne i somatyczne aborcji, vide: wywiad Aliny Czerskiej z dr. Januszem Wojewódzkim: „To musisz wiedzieć”, Prz, nr 22, 31.05.1990, 6.

23 „O narodzonych i nie narodzonych”, Prz, nr 27, 5.07.1990, 6; Ruta Pragier, „Kobieta, prawo i życie”, Prz, nr 28, 12.07.1990, 6; „Chcemy o tym decydować”, $Z w, \mathrm{nr} 15$, 20.04.1989, 2.

24 „Piekło kobiet”, KiŻ, nr 16, 19.04.1989, 4-5; „Oświadczenie Zarządu Głównego Towarzystwa Rozwoju Rodziny w sprawie projektu ustawy o prawnej ochronie dziecka poczętego”, Ki்̇, nr 27, 5.07.1989, 10; Ika, „Dwa lata więzienia za przerwanie ciąży: Piekło - 1992”, Kï̇, nr 49, 2.12.1992, 2-3.

25 Elżbieta Wierzbicka, „Paskudna sprawa”, Ki்̇, nr 43, 24.10.1990, 5, 22.

26 Rozmowa Danuty Bierzańskiej z prof. Anną Przecławska: „Koło Ratunkowe”, Ki்̇, nr 9, 1.03.1989, 4-5; rozmowa Zygmunta Włoczewskiego z prof. Anną Przecławska, Prz, nr 14, 6.04.1989, 5 .

27 „O nas bez nas (1)”, Krystyna Kaszuba (oprac.), KiŻ, nr 13, 29.03.1989, 4-5; „O nas bez nas (2)”, oprac. eadem, KiŻ, nr 14, 5.04.1989, 2; „O nas bez nas”, nr 45, 22.11.1989, 5; Bożena Stolarska, „Liczby o Polce”, Zw, nr 15, 20.04.1989.

28 Vide szerzej: Anna Szwed-Walczak, „Obraz wyborów kontraktowych w Polsce na łamach prasy dla kobiet”, Czasopismo Naukowe Instytutu Studiów Kobiecych, nr 1, 2019, 157.

${ }^{29}$ Rozmowa Wiesławy Lipińskiej z prof. Arturem Bodnarem: „Budować od dołu”, Zw, nr 6, 9.02.1989, 4. 
od razu wszystko zmieni na lepsze. Reformowanie naszej rzeczywistości, choć ze zmiennym szczęściem, trwa od dłuższego czasu”30. Podobne sformułowania pojawiły się w tygodniku „Kobieta i Życie”. Za niekwestionowaną i dostrzegalna zaletę obrad uznano usankcjonowanie istnienia opozycji demokratycznej w Polsce ${ }^{31}$.

Atencję wzbudziły również będące konsekwencją obrad Okragłego Stołu wybory kontraktowe ${ }^{32}$. Prasa dla kobiet właczyła się w kampanię wyborczą. Prezentowano sylwetki polityków, na których zdaniem redakcji warto zagłosować. Informowano o procedurach głosowania. Spisywano obietnice przedwyborcze ${ }^{33}$. Stworzono rubryki, w których prezentowano opinie o kobietach, które sprawdziłyby się u władzy (w „Kobiecie i Życiu” były to: „One nie zawioda”, „Nasza Dziesiątka”; w „Przyjaciółce”: „Popieramy”) $)^{34}$. Badane czasopisma włączyły się też w akcje „Głosuj na kobiety"35. Czesława Górska, kandydatka na posłankę promowana przez „Przyjaciółkę”, pisała: „Kobiety - apeluję - głosujcie na kobiety. Nie wycinajmy się, bo kto przedstawi i załatwi to, co dla nas najważniejsze?”36. W „Przyjaciółce” wśród wytypowanych kandydatów byli również mężczyźni, którzy popierali program redakcji ${ }^{37}$. „Zwierciadło” w czasie kampanii wyborczej wyróżniło kandydatki na posłanki działające w Lidze Kobiet Polskich ${ }^{38}$, tj.: Elżbietę Lęcznarowicz, przewodniczącą Zarządu Głównego LKP, Elżbietę Gacek, wiceprzewodnicząca LKP, wicemarszałek Sejmu,

\footnotetext{
30 Wiesława Piątek, „Nie zmarnujmy tej szansy!”, Prz, nr 8, 23.02.1989, 4; eadem, „Na dobry poczatek", Prz, nr 16, 28.04.1989, 4.

31 Anna Cis, „Zadecyduja fakty”, KiŻ, nr 16, 19.04.1989, 5.

32 Elżbieta Banasiak, „Wiosna w polskim parlamencie”, Prz, nr 14, 6.04.1989, 2.

${ }^{33}$ Fra, „Jak głosujemy”, KiŻ, nr 22, 31.05.1989, 11; „Trzymamy za słowo”, Ki்̇, nr 23, 7.06.1989, 4; Wiesława Piątek, „By wybierać dobrze”, Prz, nr 18, 4.05.1989, 4; Ewa Euszczuk, „Wszystko co służy Polsce”, Prz, nr 20, 18.05.1989, 4; Elżbieta Banasiak, „Hyde Park po warszawsku”, Prz, nr 21, 25.05.1989, 5; Elżbieta Wierzbicka, „Przedwyborcza ściagaczka", $Z w$, nr 19, 11.05.1989, 5.

34 „One nie zawioda”, Ki், nr 20, 17.05.1989, 4-5, 7, 12; „Popieramy: Elżbietę Lęcznarowicz, Marię Łopatkowa, Małgorzatę Niepokulczycka, Alinę Tepli”, Prz, nr 22, 1.06.1989, 3; „Wybierzmy najlepszych”, Prz, nr 22, 1.06.1989, 4.

35 Komisja Porozumiewawcza Środowisk Kobiecych ds. Wyborów, „Głosuj na nas”, Prz, nr 22, 1.06.1989, 4; Komisja Porozumiewawcza Środowisk Kobiecych ds. Wyborów, „Głosuj na kobiety”, $Z w$, nr 20, 18.05.1989, 5; „Głosuj na kobiety”, $Z w, \mathrm{nr} 21$, 25.05.1989, 2.

36 „Popieramy: Czesławę Górska, Andrzeja Bilika, Waldemara Zmaczyńskiego”, Prz, nr 21, 25.05.1989, 4.

37 Ibidem; „Popieramy: Aleksandra Kwaśniewskiego, Stanisława Kwiatkowskiego, Leszka Millera, Dariusza Przywieczerskiego", Prz, nr 22, 1.06.1989, 5.

38 Vide szerzej: Małgorzata Dajnowicz, „Posłanki Ligi Kobiet Polskich”, 208-215.
} 
Zofię Kędzior, wiceprzewodniczącą LKP, Alinę Tepli, członka Zarządu LKP ${ }^{39}$. W „Kobiecie i Życiu” przed wyborami opublikowano sylwetki dziesięciu kobiet, które zdaniem redakcji należało poprzeć w wyborach ${ }^{40}$. Cztery z nich: Alina Tepli, Anna Szymańska-Kwiatkowska, Zofia Als-Iwańska, Małgorzata Niepokulczycka znalazły się na liście wyborczej ${ }^{41}$. Szczególna uwage poświęcono redaktor tygodnika „Kobieta i Życie”, której hasło wyborcze głosiło: „Kobiety wszystkich kolejek - łączcie się!”42. Jako jedyna $z$ promowanych przez redakcję kobiet uzyskała mandat posła. Pozostałe kandydatki nie kryły rozgoryczenia z przejmowania przez mężczyzn elektoratu kobiecego poprzez manifesty walki o prawa kobiet ${ }^{43}$.

Po wyborach podkreślano konieczność wypracowania przez kobiety pozycji adekwatnej do ich liczebności w państwie ${ }^{44}$, takiej, z która liczyłyby się wszystkie siły polityczne ${ }^{45}$. Anna Szymańska-Kwiatkowska wskazała, że celem jej udziału w wyborach było zwrócenie uwagi publicznej na „problem uczestnictwa kobiet w życiu publicznym i ich faktycznego, a nie formalnoprawnego uprawnienia” dla dobra rodzin i w interesie społecznym $^{46}$. Pojawiły się również głosy, że należy „Odkobiecić kwestie uważane za kobiece, bo to sa sprawy wszystkich, tyle tylko, że kobiety je załatwiaja"47.

Mimo że reprezentacja kobiet w parlamencie kontraktowym była niewielka ${ }^{48}$, to prasa dla kobiet doceniała fakt, że w nowym układzie po-

39 „Głosuj na kobiety”, Zw, nr 22, 1.06.1989, 8-9.

40 "Nasza "Dziesiątka". Zdaniem "Kobiety i Życia" - "One nie zawiodaı!", KiŻ, nr 20, 17.05.1989, 13-15

41 „One nie zawioda!”, Kì், nr 22, 31.05.1989, 2-3.

42 Danuta Bierzańska, Olga Oswaldo, „Goraczka demokracji”, KiŻ, nr 22, 31.05.1989, 4; „Popieramy Annę Szymańską-Kwiatkowską, Prz, nr 22, 1.06.1989, 4.

43 Małgorzata Niepokulczycka, „We wstecznym lusterku”, KiŻ, nr 26, 28.06.1989, 2.

44 Często przywoływano statystyki wskazujace, że liczebna przewaga kobiet w Polsce zaczyna się już w wieku 22 lat, ponadto Polki żyją osiem lat dłużej od Polaków, vide np.: Bożena Stolarska, „Liczby o Polce”, 6.

45 Alina Tepli, „Nie czuję się przegrana”, Ki்̇, nr 28, 12.07.1989, 12; (Prag.), „Raczkuje kobiece lobby", Prz, nr 48, 29.11.1990, 5.

46 Anna Szymańska-Kwiatkowska, „Czas nagli”, Ki்̇, nr 28, 12.07.1989, 2-3.

47 Wywiad Ruty Pragier $z$ doc. Danuta Markowską: „Dziś o tym, czy w Polsce potrzebna jest partia kobiet", Prz, nr 13, 29.03.1990, 2.

48 Od poprzedniej kadencji liczba kobiet w Sejmie zmniejszyła się z $1 / 5$ na $1 / 7$. Mandaty otrzymało 68 kobiet, w tym 62 poselskie oraz 6 senatorskich. Średnia wieku posłanek wyniosła 46,8 lat. $54 \mathrm{z}$ nich sprawowało mandat po raz pierwszy. 16 kobiet było bezpartyjnych, pozostałe reprezentowały: Polski Zwiazek Katolicko-Społeczny (1), Polska Zjednoczoną Partię Robotniczą (31), Stronnictwo Demokratyczne (3), Unię Chrześcijańsko-Społeczną (1), Zjednoczone Stronnictwo Ludowe (10). Podkreślano, że 17 województw nie ma swojej reprezentantki. Średnia wieku senatorek była wyższa i wyniosła 52,5 roku. 
litycznym pojawiła się zorganizowana opozycja demokratyczna ${ }^{49}$. Oczekiwano na w pełni demokratyczne wybory, licząc na zmianę polityki wobec kobiet. Krytycznie podchodzono do nieobsadzenia po wyborach stanowiska szefa biura pełnomocnika rzadu do spraw kobiet. Uznano to za dowód lekceważenia pracy kobiet. W „Kobiecie i Życiu” postulowano o realne równouprawnienie płci. $Z$ obawa pisano: „Polska jest jedynym krajem w Europie, w którym od 10 lat spada udział kobiet w parlamencie, a ich obecność na szczytach władzy jest tak znikoma, że trudno mówić o ich znaczacym wpływie na kształt decyzji politycznych"50. Mimo tych sceptycznych wniosków w $1991 \mathrm{r}$., przed w pełni wolnymi wyborami parlamentarnymi, tylko tygodnik „Kobieta i Życie” stworzył platformę prezentacji stanowisk kobiet kandydujących $z$ różnych opcji politycznych do Sejmu ${ }^{51}$.

Redakcje badanych tytułów prasowych były zgodne w ocenie działań społeczno-politycznych kobiet. Zauważono, że są aktywne przede wszystkim lokalnie, nie chca kandydować w wyborach parlamentarnych. Przyczynę tego zjawiska dostrzegano w przekonaniu kobiet, że „bardziej interesowałyby się polityka, gdyby w większym stopniu dotyczyła ona codziennych spraw" ${ }^{\prime 2}$.

Nie miały doświadczenia parlamentarnego oraz nie były zwiąane $z$ żadna partia polityczna, vide: Anna Szymańska-Kwiatkowska, „Czas nagli”, 2-3; Wiesława Piątek, „Parlament w nowym kształcie”, Prz, nr 29, 20.07.1989, 4; Barbara Adamczewska, „Kobiety w Sejmie i w Senacie”, $Z w$, nr 27, 6.07.1989, 2; „Kobiety w Sejmie X kadencji i w Senacie”, Zw, nr 31, 3.08.1989, 5 .

49 Grażyna Musiałek, „Inauguracja”, KiŻ, nr 29, 19.07.1989, 2-3; Anna Szymańska, „Czas teraźniejszy: "Prezydent porozumienia»”, KiŻ, nr 31, 2.08.1989, 3; Danuta Bierzańska, „Premier Tadeusz Mazowiecki: Polska będzie inna, jeśli zechcą tego wszyscy”, KiŻ, nr 34, 6.09.1989, 4; Elżbieta Banasiak, „Czas na działanie”, Prz, nr 27, 6.07.1989, 4.

50 Anna Szymańska, „Ozdobnik”, KiŻ, nr 48, 13.12.1989, 3.

51 Wśród nich znalazły się: Olga Krzyżanowska, wicemarszałek Sejmu, kandydatka Komitetu Wyborczego Unii Demokratycznej; Izabella Nowacka, przewodnicząca Ligi Kobiet Polskich, kandydatka Ruchu Demokratyczno-Społecznego; Barbara Różycka-Orszulak, zastępca redaktora naczelnego tygodnika „Razem”, kandydatka Konfederacji Polski Niepodległej; Danuta Waniek, przewodniczaca Demokratycznej Unii Kobiet, kandydatka Sojuszu Lewicy Demokratycznej; Katarzyna Wasiutyńska-Latałło, dwukrotnie we władzach Związku Plastyków, członek Zjednoczenia Chrześcijańsko-Narodowego, kandydatka Wyborczej Akcji Katolickiej, vide: Iwona Konarska, „Wybrać nie tylko wolność”, KiŻ, nr 43, 23.10.1991, 2-3.

52 Danuta Bierzańska, „Ponad głowami”, 4-5; rozmowa Zygmunta Włoczewskiego z Małgorzatą Kielską-Żukowską: „Chcemy się rządzić sami”, 5; Mieczysław Machnicki, „Czy kobieta może być politykiem?”, Zw, nr 9, 09.1991, 14-15. 
Z mniejszym zainteresowaniem śledzono przebieg kampanii wyborczej samorządowej i prezydenckiej w 1990 r. ${ }^{53}$ Przed wyborami prezydenckimi w 1990 r. redakcja „Kobiety i Życia” jawnie poparła dwie kandydatury na urząd prezydenta - Tadeusza Mazowieckiego oraz Lecha Wałęsy ${ }^{54}$. W redakcji „Zwierciadło” opowiedziano się zaś za Tadeuszem Mazowieckim ${ }^{55}$.

$\mathrm{Na}$ łamach prasy dla kobiet prowadzono za to kampanię profrekwencyjną. Udział w wyborach traktowano jako obowiąek obywatelski. W 1989 r. w „Przyjaciółce” apelowano: „Nadchodzi moment, w którym - w Twoim własnym i naszym wspólnym interesie - trzeba się włączyć w bieg wydarzeń" ${ }^{\text {. N }}$ Na łamach „Zwierciadła” przypominano, że „Demokracja wymaga aktywności” ${ }^{7}$. W 1991 r. redakcja „Kobiety i Życia”, podkreślając ważność wyborów demokratycznych, ostrzegała czytelniczki: „Jeden nieostrożny krok i znowu możemy się znaleźć wśród pustych półek i kartek na buty” ${ }^{58}$. „Przyjaciółka” w celu mobilizacji kobiecego elektoratu zainicjowała cykl artykułów „To Pani wybiera, Pani Kowalska”59.

Zaskakujące jest, że na łamach prasy dla kobiet nie zainteresowano się pracami nad nowa konstytucją. Odniesiono się do nich wyłącznie w tygodniku „Kobieta i Życie”60.

Przemiany polityczne nie zaangażowały kobiet w działalność na rzecz własnych interesów. Na łamach „Kobiety i Życia” zaznaczono, że to projekt ustawy o ochronie dziecka poczętego zwrócił uwagę na sytuację

\footnotetext{
53 „Nasz prezydent”, Ki்̇, nr 47, 21.11.1990, 11; „Kalendarium wyborcze (wg „Rzeczpospolitej”)”, Prz, nr 17, 26.04.1990, 4; „Jak będziemy wybierać prezydenta: Vademecum wyborcy", Prz, nr 45, 8.11.1990, 4.

${ }^{54}$ Agnieszka Metelska, „Droga do Belwederu”, KiŻ, nr 47, 21.11.1990, 4-6.

55 „Nasz Premier - Nasz Prezydent Tadeusz Mazowiecki”, Zw, nr 45, 8.11.1990, 3-4.

56 Redakcja, „Przed wyborami do Sejmu i Senatu: przeczytaj, zastanów się, przedstaw swój pogląd”, Prz, nr 19, 11.05.1989, 4.

57 Elżbieta Wierzbicka, „Wybierasz dla siebie”, Zw, nr 20, 17.05.1990, 2-3.

58 Joanna Młynarczyk, „Licytacja skończona”, Ki்̇, nr 43, 23.10.1991, 2.

59 Elżbieta Banasiak, „To Pani wybiera, Pani Kowalska”, Prz, nr 37, 12.09.1991, 4; Ruta Pragier, „To Pani wybiera, Pani Kowalska: Tylko dla dorosłych”, Prz, nr 38, 19.09.1991, 4; Elżbieta Banasiak, „To Pani wybiera, Pani Kowalska: Oko w oko z kandydatem”, Prz, nr 39, 26.09.1991, 4; eadem, „To Pani wybiera, Pani Kowalska: Wymagania "złotej główki»”, Prz, nr 40, 3.10.1991, 4; Ban. (oprac.), „To Pani wybiera, Pani Kowalska: Co do ordynacji wyborczej warto wiedzieć”, Prz, nr 41, 10.10.1991, 4; eadem (oprac.), „To Pani wybiera, Pani Kowalska: Co do ordynacji wyborczej warto wiedzieć (2)", Prz, nr 42, 17.10.1991, 4; eadem (oprac.), „To Pani wybiera, Pani Kowalska: Co do ordynacji wyborczej warto wiedzieć (3)”, Prz, nr 43, 24.10.1991, 4; Zofia Kamińska, „4220 dni Żelaznej Damy”, KiŻ, nr 3, 16.01.1991, 12-13; wywiad Natalii Iwaszkiewicz z Barbara Malak, KiŻ, nr 33, 15.08.1990, 2-3.

60 „Od majowej do powstającej”, KiŻ, nr 18, 2.05.1990, 2.
} 
kobiet w Polsce, „... dopiero walka o prawo do własnego brzucha obudziła $\mathrm{w}$ wielu $\mathrm{z}$ nich świadomość więzów płci" ${ }^{\prime}$. W tygodniku oceniano, że kobiety „odzyskały siłę w proteście”62. Iwona Konarska pisała: „Całkiem niedawno odkryłyśmy, że demokracja jest rodzaju męskiego. Jeśli pomimo wszystko, chcemy w niej uczestniczyć, musimy być uparte. Domagać się referendum w sprawie aborcji. Wbrew pozorom pytania w nim zawarte nie są monotematyczne. Dotyczą naszej godności”63.

\section{Rola kobiet w okresie przemian transformacyjnych}

Jak zauważyła Zofia Sokół, już w 1988 r. w zwiąku z projektem ustawy o prawnej ochronie dziecka poczętego i penalizacji aborcji wizerunek kobiety na łamach „Kobiety i Życia” ewoluował z „kobiety-feministki” do „kobiety politycznej”64, co przejawiało się w walce o jej miejsce w strukturze pracy, gospodarki i działalności politycznej (dział „Awanse i kariery") i nasilało się wraz z kampanią wyborczą do Sejmu i Senatu w 1989 r. i 1991 r. Tendencja ta pojawiła się też na łamach „Przyjaciółki” i „Zwierciadła”. Wiązało się to z promocja odmiennej od tradycyjnej roli kobiety. $\mathrm{W}$ badanych czasopismach uznano bowiem, że przemiany transformacyjne stanowią okazję do rozpoczęcia przemian świadomości społeczeństwa polskiego.

W styczniu 1989 r., wraz z doniesieniami o zbliżających się obradach Okragłego Stołu, proces transformacji ustrojowej postrzegano jako szansę na zmianę sytuacji kobiet. W tygodniku „Kobieta i Życie” ten stan rzeczy nie trwał jednak długo, gdyż teza o tym, że przemiany polityczne ugruntuja równouprawnienie kobiet, została zachwiana wraz $z$ inauguracją obrad Okragłego Stołu, w której uczestniczyła wyłącznie jedna kobieta (i pięćdziesięciu sześciu mężczyzn), a w czasie pracy podstolików nie poruszano problemów kobiet. Renata Siemińska politykę wobec kobiet określiła wówczas stanem „O nas bez nas”65. Redakcja „Kobiety

${ }_{61}$ Agnieszka Metelska, „Polki pokorne, Polki zbuntowane”, KiŻ, nr 50, 11.12.1991, 6-7.

62 Ibidem.

${ }^{63}$ Iwona Konarska, „Dwa teatry”, Ki்̇, nr 18, 29.04.1992, 2; „Grozi nam przymus rodzenia”, Prz, nr 51, 17.12.1992, 4.

${ }^{64}$ Zofia Sokól, „Wizerunki kobiet na łamach tygodnika "Kobieta i Życie» w latach 19462002", Rocznik Prasoznawczy, R. VI, 2012, 25.

65 „O nas bez nas (1)”, 4. 
i Życia” manifestacyjnie zorganizowała konkurencyjne obrady damskiego stołu, w trakcie których podejmowano „sprawy kobiece”.

Na łamach „Kobiety i Życia” oraz „Zwierciadła” wyjaśniano niereprezentatywność kobiet we władzy. Wskazano, że po II wojnie światowej manipulowano równouprawnieniem kobiet w celu realizacji bieżaccej polityki państwa ${ }^{66}$. Promowano wzorce traktorzystek, murarek, urzędniczek, nauczycielek i obiecywano „wyzwolenie przez pracę”, „pomijając skrzętnie fakt, że u podstaw prawa do pracy leżało pierwotne założenie, iż podjęcie działalności zawodowej jest wynikiem wolnego wyboru, chęci samorealizacji na forum publicznym, a nie koniecznością i obowiąziem"67. Mimo aktywności zawodowej Polek (w 1979 r. stanowiły 43,2\% zatrudnionych) i wyższego niż u mężczyzn poziomu wykształcenia traktowano je jak pracowników drugiej kategorii, co przejawiało się w niższych zarobkach oraz zatrudnianiu na stanowiskach zagrażajacych ich życiu ${ }^{68}$. Prawo pracy dla kobiet nie zostało też właściwie zabezpieczone, gdyż nie stworzono warunków socjalnych na ich realizację zawodowa tj. infrastruktury przedszkolnej, żłobków, rozbudowanej sieci świetlic i stołówek. Podkreślano, że kobiety stanowiły połowę członków „Solidarności”, a mimo to nie zadbano o ich interesy. Za przyczynę tego stanu uznano fakt, że pojmowały one swój los jako wspólny $z$ mężczyznami, nie czuły interesu grupowego własnej płci69.

Za priorytet uznano więc rozbudzenie świadomości grupowej kobiet, pozbawienie ich kompleksu niższości i poczucia winy, że nie wywiązuja się właściwie ze wszystkich narzuconych obowiązków. Dopiero po tym możliwe będzie rozbudzenie motywacji do udziału w życiu zawodowym i publicznym. Elżbieta Lęcznarowicz wskazała, że bariera w rozwoju aktywności Polek jest brak partnerstwa w rodzinie. Zaapelowała o wspólne działanie na rzecz tworzenia klimatu solidarności kobiet. Barbara Sass uzależniała zmianę świadomości od rozwoju gospodarki, gdyż kobiety w Polsce były jej zdaniem ofiarami kryzysów ekonomicznych. Wyszczególniła jeszcze jedna przeszkodę aktywności, wskazując, że „kobiety w Polsce, w przeciwieństwie do Niemek, Amerykanek czy Francuzek,

${ }^{66}$ Ibidem, 4; Ewa Nowakowska, „Kto płaci”, Zw, nr 10, 9.03.1989, 3; Krystyna Stachowicz, „Kobiety mówią NIE”, $Z w$, nr 11, 15.03.1990, 2-3.

67 Barbara Limanowska, „Dlaczego ogórek nie śpiewa”, Ki்̇, nr 11, 15.03.1989, 2-3.

68 Wywiad Renaty Marzewskiej z mgr Renatą Grabską: „Kobieta wytrzyma więcej”, Ki்̇, nr 5, 1.02.1989, 2-3; Barbara Limanowska, „Dlaczego ogórek nie śpiewa”, 3.

69 Agnieszka Metelska, „Polki pokorne, Polki zbuntowane”, 6-7. 
wstydzą się, że sa kobietami. Tak zostały wychowane"70. Irena Reszke uznała, że w Polsce należy pobudzić „świadomość feministyczną kobiet, żeby chciały i mogły mówić za siebie w swoich sprawach, a nie czekały, że ktoś coś za nie zrobi" ${ }^{\prime 1}$. Danuta Waniek proponowała, aby utworzyć Centrum Kobiet Rzeczypospolitej jako platformę porozumienia różnych organizacji kobiecych $^{72}$. Dostrzegano jednak brak liderek politycznych ${ }^{73}$. W rubryce „Jeśli nie my, to kto” Krystyna Kaszuba podsumowała debatę między kobietami słowami: „Jesteśmy ogromną siła polityczna, stanowimy w skali kraju ponad 50\% elektoratu, a w Łodzi na pewno więcej. Tylko od nas zależy czy $z$ tą siłą trzeba będzie się liczyć"74.

Zachęcano także kobiety do refleksji nad ich przyszłością. Monika Teresińska pytała: „A więc przede wszystkim zastanówmy się, jak chcemy przeżyć lata, które nam pozostały: jako kobiety kariery które wskutek tego żywią rodzinę w stołówkach i mają kurz na półkach, czy jako nadzwyczajne panie domu, w którym trudno będzie awansować?"75. Anna Szymańska-Kwiatkowska, redaktor naczelna „Kobiety i Życia”, zadeklarowała: „Jako kobieta jestem przeciwna karykaturalnemu modelowi kobiety umęczonej, $z$ siatami, jako naczelna - muszę podpowiadać takie rozwiąania, które nasze życie uczyniłby łatwiejszym, jako posłanka - starać się zmieniać archaiczną optykę widzenia gospodarki i roli kobiety"76.

Manifestowano również sprzeciw wobec utrwalaniu w podręcznikach szkolnych stereotypowych ról w rodzinie, gdzie status kobiety utożsamiany jest $z$ rolą matki, ojca $z$ pozycją zawodowa ${ }^{77}$. Redakcja „Kobiety i Życia” zainicjowała również akcję sprzeciwu wobec wypowiedziom obrażającym kobiety, podważajacym ich kompetencje, łamiacym ich prawa. Nagrodę „za najbardziej antykobiece wystapienia i wypowiedzi” nazwano Rogiem. Pierwszą nagrodę otrzymał szef Urzędu Rady Ministrów

\footnotetext{
70 „O nas bez nas (1)”, 4.

71 "O nas bez nas (2)", 3.

72 (mm), „8 lipca zamiast 8 marca?”, $Z w, \mathrm{nr} 4,25.01 .1990,4$.

73 "O nas bez nas (2)", 3.

74 „Jeśli nie my, to kto?”, Krystyna Kaszuba (oprac.), KiŻ, nr 20, 17.05,1989, 3.

75 Monika Teresińska, „Bariery awansu: Polski schemat”, KiŻ, nr 34, 6.09.1989, 2.

76 Wywiad Anny Sułkowskiej z Anną Szymańską-Kwiatkowską: „2000 razy kobieta”, Prz, nr 41, 12.10.1989, 6-7.

77 Wywiad Ewy Dobrowolskiej z Izabelą Nowacka z Ośrodka Dokumentacji i Informacji Naukowej przy Zarządzie Głównym Ligi Kobiet Polskich: „Niech mama czegoś pragnie”, Zw, nr 10, 9.03.1989, 2; Zofia Zubczewska, „Wymyślony świat”, KiŻ, nr 6, 7.02.1990, 3-4.
} 
- Wojciech Włodarczyk za zwolnienie Anny Popowicz, pełnomocnik rzadu ds. rodziny, kobiet i młodzieży i likwidację urzędu (zwolnił też 9 innych kobiet i jednego mężczyznę), drugi Róg dostał Janusz Korwin-Mikke ${ }^{78}$.

Poza diagnoza sytuacji kobiet $\mathrm{w}$ badanej prasie zwracano uwage na ich predyspozycje do rządzenia państwem. Swoje miejsce dostrzegały w resortach, gdzie podejmuje się decyzje dotyczące „domu, rodziny, zdrowia, oświaty, ochrony środowiska"79. Zwracano uwage na kompetencje społeczne kobiet, np. w tygodniku „Kobieta i Życie” wskazano, że są mniej skłonne do przemocy oraz bardziej tolerancyjne niż mężczyźni, w polityce sa skłonne łączyć siły i działać ponadpartyjnie na rzecz zdrowia oraz oświaty. Iwona Konarska stwierdziła: „Wojna na górze jest wojna mężczyzn"80. Barbara Labuda $z$ własnych obserwacji wnioskowała, że kobiety w życiu publicznym maja „skłonność do szukania porozumienia, do dialogu, do negocjowania i odnajdywania pozytywnych stron problemu. W życiu publicznym bardziej zależy im na sprawie, niż na eksponowaniu siebie, co bliższe jest mężczyznom. Mężczyźni potrafią zarysować wielkie, strategiczne cele, ale dojdą do nich dzięki kobietom"11. Zofia Kuratowska zauważyła: „Kobiety mają na ogół mniej osobistych ambicji politycznych ... za to więcej wytrwałości w mrówczej pracy. A ten Sejm takiej pracy wymaga. Większość moich koleżanek posłanek tak właśnie porządnie, rzeczowo pracuje i popycha mało widoczną, a konieczną robotę poza sala obrad plenarnych" 82 .

Zatem kolejna zaleta kobiet predestynująca je do udziału we władzach była gotowość do ciężkiej pracy: „Bo one po prostu robią swoje, nie patrzac do góry" ${ }^{33}$. $Z$ tego wynikać miała również ich niereprezentatywność na stanowiskach kierowniczych. Jak ujęła Agnieszka Metelska: „Kobieto, ty wieczny zastępco - utarło się w potocznej mowie”84. Barbara Labuda dostrzegła, że „kobiety w świecie polityki są traktowane jako

\footnotetext{
78 Iwona Konarska, „Durna Blondynka”, KiŻ, nr 18, 29.04.1992, 4; eadem, „Wręczamy "Róg" po raz drugi", KiŻ, nr 27, 1.07.1992, 15.

79 Lidia Błaszczyk, „Odpoczynek wojownika”, KiŻ, nr 21, 20.05.1992, 2.

80 Wywiad Teresy Gałczyńskiej z Ewą Osiatyńską: „Wernisaż dusz”, Ki̇̇, nr 2, 11.01.1989, 17; Iwona Konarska, „Pułapka”, KiŻ, nr 39, 25.09.1991, 4-5.

81 Wywiad Iwony Konarskiej z Barbara Labudą: „Czarownice w Sejmie”, KiŻ, nr 40, 2.10.1991, 5 .

82 Wywiad Grażyny Chlebowskiej z wicemarszałkiem Sejmu Olgą Krzyżanowska: „Musi się udać", $Z w$, nr 27, 5.07.1990, 3.

83 Wywiad Natalii Iwaszkiewicz z Barbara Malak, 2-3.

84 Agnieszka Metelska, „Nasza Rówieśnica”, KiŻ, nr 6, 6.02.1991, 2-3.
} 
wieczni terminatorzy, uczennice, produkt niepełny. Bez przerwy muszą udowadniać, że sa niezłe w tym, co robią. To sprawia, że część z nich - najbardziej przedsiębiorcze, ekspansywne i inteligentne rzeczywiście staja się coraz lepsze. Gdyby były mężczyznami, miałyby już bardzo wysokie stanowiska, a tu traca czas na udowadnianie, że sa dobre"85. Brak angażu kobiet w polityce skłonił redakcje „Kobiety i Życia” do powołania w prima aprilis „damskiego gabinetu cieni”86. Redakcja zwróciła uwagę, że rząd powołano „mało demokratycznie, zgoda, ale skoro demokracja na razie służy tylko mężczyznom, musimy sobie jakoś radzić!’"7. Podkreślano, że w Polsce nie uwzględnia się potencjału intelektualnego i zawodowego kobiet, co szczególnie szkodliwe jest dla państwa ${ }^{88}$.

Odwoływano się też do doświadczenia kobiet w zarządzaniu gospodarstwem domowym w czasie permanentnego kryzysu gospodarczego. Wskazano, że to kobiety mogłyby uporządkować i zorganizować gospodarkę krajową ${ }^{89}$. Zauważono, że mężczyźni w zarządzaniu gospodarką pomijaja zasady racjonalnego działania oraz maksymalizacji efektu przy niskich nakładach, realizowane przez kobiety w gospodarstwie domowym $^{90}$. Redakcja „Kobiety i Życia” dostrzegała w dopuszczeniu kobiet do zarządzania szansę na „uspokojenie emocji, zmianę języka polityki, złagodzenie obyczajów, zmianę stylu rządzenia krajem”1. W prasie dla kobiet powołanie rządu Hanny Suchockiej ujmowano jako symbol walki o miejsce problematyki kobiecej w sferze publicznej. O tym wydarzeniu pisano: „W świadomości społecznej ten wybór może dokonać

85 Wywiad Iwony Konarskiej z Barbara Labuda, 5.

86 Deklarowano: „Mamy przecież wszystko: wiedzę, doświadczenie, walory intelektualne, upór, konsekwencję, wizję, pomysły, logikę działania. Także ciepło, zrozumienie, wreszcie urodę, wdzięk, odrobinę kokieterii także. Żadne tam cienie”, vide szerzej: „Czy demokracja jest rodzaju męskiego?”, KiŻ, nr 14, 1.04.1992, 3; "Gabinet do wzięcia”, Ki்̇, nr 14, 1.04.1992, 8-9. Mimo żartobliwych okoliczności powołania gabinetu zaangażowane kobiety zwołały posiedzenie, którego efektem była inicjatywa gromadzenia funduszu wakacyjnego dla polskich dzieci $z$ najuboższych rodzin $z$ kraju, ale też z Kazachstanu, Litwy i Białorusi, „Wierzymy w kobietę. Czy demokracja jest rodzaju męskiego? Uparcie wołamy - NIE!”, KiŻ, nr 16, 15.04.1992, 8-9; „Czy demokracja jest rodzaju męskiego: Gabinet nadal... do wzięcia”, KiŻ, nr 26, 24.06.1992, 6.

87 "Czy demokracja jest rodzaju męskiego?”, 22.

88 "O nas bez nas (2)", 3.

89 Krystyna Kaszuba, „Za zamkniętymi drzwiami”, Ki்̇, nr 4, 25.01.1989, 2; „Pisane kobiecą ręką. Listy, które w lutym i marcu br. nadeszły do uczestników Okragłego Stołu czytała i do druku podała Natalia Iwaszkiewicz", KiŻ, nr 15, 12.04.1989, 2-3.

90 K. G. M., „Bariery awansu: "Kury" biurowe i naukowe”, KiŻ, nr 27, 5.07.1989, 2-3.

91 Natalia Iwaszkiewicz, „Czy demokracja jest rodzaju męskiego? Na szczęście - NIE!: Premiera pani premier”, KiŻ, nr 31, 29.08.1992, 12. 
prawdziwego przełomu torując drogę mądrym, wykształconym, odważnym kobietom do najwyższych stanowisk państwowych"92.

W Polsce na przełomie lat 80. i 90. XX w. wprowadzono „nowa jakość do sposobu definiowania jej [kobiety] pozycji i roli w społeczeństwie, ale co ważniejsze rozpoczęły proces zmiany dotychczasowego postrzegania własnych możliwości angażowania się i autorealizacji wśród samych Polek"93. Badane tytuły prasowe były tego przykładem. Propagowały scenariusz udziału kobiet w zarządzaniu państwem. W tym celu optowano za zmianą roli kobiet w świadomości społecznej oraz prezentowano katalog kompetencji miękkich, które czyniły je skuteczniejszymi w działaniu.

\section{Formy aktywizacji społecznej i politycznej}

Irena Tetelowska wskazała, że prasa spełnia trzy podstawowe funkcje: informacyjna, kształtowania opinii i modyfikowania zachowań oraz rozrywkowa ${ }^{94}$. Przedmiotem niniejszych badań były teksty pełniące druga $z$ wymienionych funkcji. Tetelowska zauważyła, że kreowanie opinii i zmiana postaw są realizowane poprzez: 1) przedstawienie pojęć i przekonywanie do pewnej idei, 2) przedstawienie wyobrażeniowe, o charakterze ocennym, czego egzemplifikacja jest reportaż, 3) oddziaływanie poprzez wypowiedzi prasowe, narzucające opinię, wymagające zajęcia przez czytelników stanowiska, czy zaktywizowanie do działań, 4) wyrażanie emocji w felietonie, eseju ${ }^{95}$. W badanej prasie zdecydowanie dominowały wypowiedzi aktywizujące kobiety do działań i wymagające zajęcia stanowiska w sprawie. Przejawiało się to w licznych apelach do kobiet. Jednakże nie zabrakło również materiałów ocennych czy perswazyjnych, zob. wykres 1 .

92 „Europejka roku: Najlepsza wśród najlepszych”, Ki்̇, nr 42, 14.10.1992, 2-3.

93 Magdalena Boronowska, „Nowe szanse, ale czy nowoczesny sposób funkcjonowania współczesnej kobiety?”, w: Magdalena Baranowska-Szczepańska (red.), Ona w XXI wieku - interdyscyplinarny obraz kobiety, (Poznan : Instytut Naukowo-Wydawniczy Maiuscula, 2011), 137.

94 Irena Tetelowska, „Analiza zawartości gazet - wstępne stadium funkcjonalnej typologii prasy", Zeszyty Prasoznawcze, nr 4, 1962, 14.

95 Ibidem, 15. 
Wykres 1. Frekwencyjność w prasie dla kobiet kategorii kształtujących opinię

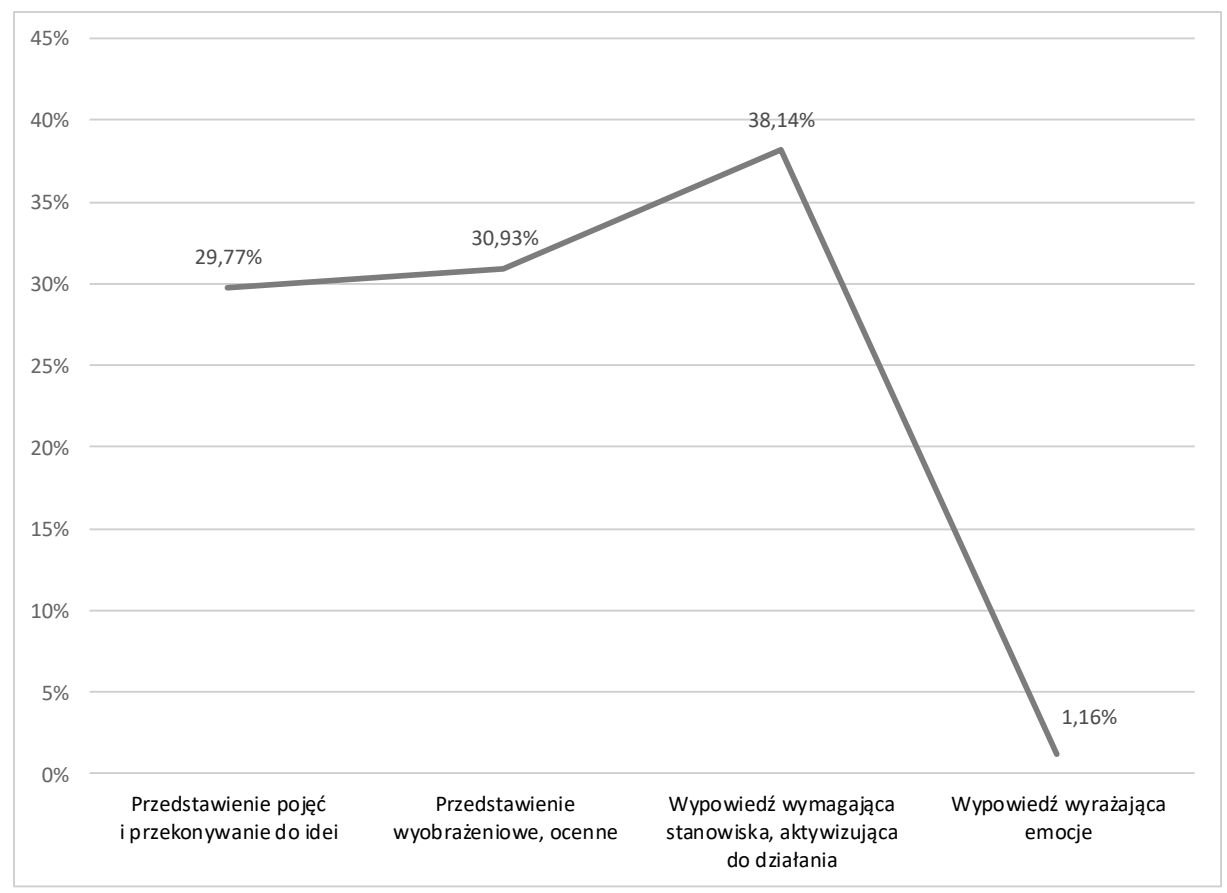

Źródło: opracowanie własne.

Dostrzec można specyfikę poszczególnych kategorii kształtujących opinię w konkretnych tytułach prasy dla kobiet. W tygodniku „Kobieta i Życie” dominowały materiały ocenne oraz aktywizujące, w tygodniku „Przyjaciółka” proporcje każdej kategorii były wyrównane. W „Zwierciadle” zaś największy udział w dyskursie miało przedstawienie pojęć i przekonanie do pewnej idei. $\mathrm{W}$ badanym okresie $\mathrm{w}$ tygodniku „Kobieta i Życie” unikano wypowiedzi wyrażających emocje, skupiając się na faktach i konkretach, zob. wykres 2 . 
Wykres 2. Udział kategorii kształtujących opinię z podziałem na poszczególne tytuły prasy dla kobiet



Źródło: opracowanie własne.

Należy zatem zaznaczyć, podażając za propozycją Ireny Tetelowskiej, że prasa dla kobiet, podejmująca się roli kreatora opinii i postaw, stosowała najczęściej wypowiedzi aktywizujące do podjęcia działań. Jednakże biorąc pod uwagę konkretny tytuł, zauważalna jest paralela formy wypowiedzi do grupy docelowej pisma. W badanym okresie redakcja „Kobiety i Życia” zdecydowanie częściej podejmowała problematykę społeczna i polityczna (zob. tabela 1), dominowały w jej przekazie wypowiedzi aktywizujace do działania i wymagajace od czytelniczek zajęcia stanowiska względem omawianej sprawy. Dodatkowo redakcja dokonywała ocen przemian politycznych i sytuacji kobiet. Pismo skierowane było głównie do mieszkanek małych miast, majacych wykształcenie średnie. Warto zaznaczyć, że to one dotkliwie odczuwały transformację ustrojowa, szczególnie w zakresie redukcji zatrudnienia ${ }^{96}$. Stanowiły również znaczna grupę $\mathrm{w}$ miastach, zatem możliwe było ich zmobilizowanie do protestów, do stworzenia kobiecego lobby, czy zachęcenie do współpracy w imię wspólnych inicjatyw biznesowych i szkoleniowych. Tygodnik

96 Wskazano, że w lipcu $1991 \mathrm{r}$. w Polsce było 1,5 mln bezrobotnych, w tym około $1 \mathrm{mln}$ kobiet, Iwona Kołodziej, „Bieda na jedwabiu”, KiŻ, nr 41, 9.10.1991, 2. 
„Przyjaciółka” trafiał przede wszystkim do kobiet wiejskich, ale miał też znacząca grupę czytelniczek miejskich (robotnic). Stąd także wykorzystano wypowiedzi aktywizujące do działania, jednak również wspierano je materiałami emocjonalnymi. Z kolei „Zwierciadło”, adresowane do kobiet wykształconych, zdecydowanie częściej od pozostałych badanych pism przedstawiało idee, wyjaśniało procesy polityczne i przekonywało do ich słuszności. Częściej stosowało też materiały wyrażające emocje.

Zasadna była odpowiedź na pytanie, w jaki sposób redakcje prasy dla kobiet zachęcały czytelniczki do aktywności politycznej, społecznej i gospodarczej. Po pierwsze prezentowano przykłady kobiet, które spełniały się, realizując karierę polityczną. Za wzorzec uznano Margaret Thatcher, wskazując, że w osiagnięciu urzędów pomógł jej wyrozumiały maż, który wspierał ją finansowo i psychicznie. W kontekście Polek, w rodzinach których model partnerstwa w małżeństwie był rzadkościa, sformułowano pytanie retoryczne: „Jak robić karierę w towarzystwie sfrustrowanych mężów, którzy sami nie zrobili kariery?”. W pismach drukowano też polskie przykłady kobiecej aktywności ${ }^{97}$. Przekrój i różnorodność sylwetek ukazywały intencje redakcji, aby nie promować jednolitego wzorca kobiecości. Pojawiły się wywiady zarówno $z$ kobietami przywiazanymi do tradycji, jak i $z$ „nowoczesnymi” aktywistkami, upatrujacymi w niej barierę $^{98} . Z$ optymizmem pisano o Hannie Suchockiej, pierwszej Polce, która została premierem: „Świetnie wykształcona prawniczka, niezależna

\footnotetext{
97 Redakcja „Zwierciadła” od lipca 1989 r. do lutego 1990 drukowała sylwetki posłanek i senatorek, vide np. Barbara Adamczewska, „Kobiety w Sejmie i w Senacie”, 2 oraz „Twoje posłanki”, $Z w$, nr 27, 6.07.1989, 2.

98 Wywiad Krystyny Kaszuby $z$ Lidią Smyczyńska, naczelna „Tygodnika Demokratycznego", KiŻ, nr 18, 3.05.1989, 4; rozmowa Alicji Bińskiej z przewodniczącą Ligi Kobiet Polskich Elżbieta Lęcznarowicz: „Blisko życia zwykłych ludzi”, Ki்̇, nr 23, 7.06.1989, 2; rozmowa Elżbiety Juszczak z senatorka $z$ województwa koszalińskiego Gabrielą Cwojdzińska, KiŻ, nr 35, 13.09.1989, 4-5; wywiad Iwony Konarskiej z Kinga Stawikowska, przewodnicząca Związku Kobiet i Dziewcząt Chrześcijańskich (YWCA), „Wywiad na zamówienie”, KiŻ, nr 6, 5.02.1992, 23; rozmowa Danuty Bierzańskiej z dr Danutą Waniek: „Niebezpieczna nieobecność", Kï̇, nr 45, 22.11.1989, 5; rozmowa Krystyny Kaszuby z wicemarszałkiem Sejmu dr Olga Krzyżanowska, „Sytuacja tworzy polityka”, Ki்̇, nr 50, 27.12.1989, 2-3; Iwona Konarska, „Na granicy demokracji”, KiŻ, nr 42, 16.10.1991, 5, 15; Małgorzata Metelska, „Będę mówiła prawdę”, KiŻ, nr 14, 4.04.1990, 3-4; rozmowa Grażyny Musiałek z Barbara Labuda, posłanka z Obywatelskiego Kluby Parlamentarnego: „Kwestia temperamentu”, Ki்̇, nr 16, 18.04.1990, 2.
} 
intelektualnie i nie poddająca się emocjom kobieta, potrafi sprostać szalenie trudnemu wyzwaniu, jakie podjęła" ${ }^{\text {. }}$.

Redakcje „Kobiety i Życia” oraz „Przyjaciółki” promowały ideę nagrody Kobiety Europy. Zaangażowały się też w wybór polskiej kandydatki do konkursu. Redakcja „Kobiety i Życia” wytypowała: Hannę Suchocka, Ewę Łętowska, Krystynę Jandę oraz Agnieszkę Holland. Te kandydatury zgłosiła również „Przyjaciółka”, dodatkowo popierając: Annę Fornalczyk, Zofię Kuratowską, Marię Łopatkową i Wandę Rutkiewicz. Ostatecznie polską nominację otrzymała Ewa Łętowska ${ }^{100}$.

Prasa dla kobiet $z$ uwaga śledziła i opiniowała powstajace pod koniec 1989 r. i na początku 1990 r. organizacje kobiece o charakterze politycznym ${ }^{101}$, tj.: Ruch 8 Lipca, Ruch Samoobrony Kobiet w Bydgoszczy, toruńskie stowarzyszenie „Godność kobiety”, Poznański Ruch na Rzecz Obrony Praw Kobiet, Pro Femina, Polskie Stowarzyszenie Feministyczne, Szczeciński Kolektyw Feministyczny, Demokratyczną Unię Kobiet ${ }^{102}$. Wskazywała na profil ich działań, ale też motywowała do integracji kobiet. W latach 1991-1992 dostrzeżono absencję organizacji kobiecych, które jeszcze na konferencji oraz podczas Forum Kobiet (w 1990 r.) spierały się o program polityczny, następnie wspólnie walczyły o własne zdrowie oraz protestowały pod Sejmem przeciwko projektowi ustawy o prawnej ochronie dziecka poczętego. Pod koniec $1991 \mathrm{r}$. ich zaangażowanie osłabiło się.

99 Natalia Iwaszkiewicz, „Czy demokracja jest rodzaju męskiego?”, 2; „Europejka roku: Najlepsza wśród najlepszych”, 2-3.

100 Wywiad Marii Mankiewicz z Anną Popowska: „Czy kobieta Europy jest wśród nas?”, KiŻ, nr 38, 16.09.1992, 2; „Europejka roku: Najlepsza wśród najlepszych”, 2-3; Ede, Ika, „Pani Europa”, KiŻ, nr 48, 25.11.1992, 2; „Nasza Europejka”, PrZ, nr 50, 10.12.1992, 5.

${ }^{101}$ Jak wskazuja badacze, transformacja ustrojowa oraz spadek liczby kobiet w Sejmie stanowiły asumpt do rozwoju tzw. „nowego ruchu kobiecego”. Formował się on wokół silnych liderek, vide: Małgorzata Fuszara, „Zmiana w świadomości kobiet w Polsce w latach dziewięćdziesiątych", w: eadem (red.), Kobiety $w$ Polsce na przełomie wieków. Nowy kontrakt płci?, (Warszawa : Instytut Spraw Publicznych, 2002), 30-31; Anna Titkow, „Interes grupowy polskich kobiet", w: Małgorzata Fuszara (red.), Kobiety w Polsce, 55-56.

${ }_{102}$ Mariusz Załuski, „Kobieta też człowiek”, Ki̇̇, nr 44, 15.11.1989, 5; rozmowa Danuty Biebrzańskiej z dr Danuta Waniek: „Niebezpieczna nieobecność”, 5; rozmowa Krystyny Kaszuby z Jolantą Plakiewcz, KiŻ, nr 45, 22.11.1989, 5; (Prag.), „Raczkuje kobiece lobby”, 5; „Remanent damskich spraw”, rozm. Elżbieta Banasiak, Prz, nr 4, 24.01.1991, 4-5; (AMW), „Kobiety uderzyły pięścia w stół: chora przyszłośč”, Prz, nr 31, 1.08.1991, 5; rozmowa Elżbiety Wierzbickiej z Jolantą Plakwicz i Anną Siwek, „Ruch - którego nie ma?”, $Z w, n r$ 24, 15.06.1989, 3; Elżbieta Wierzbicka, „Zaczyna się RUCH”, Zw, nr 47, 7.12.1989, 2-3; rozmowa Ruty Pragier z Danutą Waniek: „Dziś o tym, czy kobiety potrafia bronić swych praw”, Prz, nr 15, 11.04.1991, 2; Prezydium Demokratycznej Unii Kobiet, „Apel do kobiet polskich”, Prz, nr 32, 8.08.1991, 3; rozmowa z Danuta Waniek: „Ani gorsze, ani mniej atrakcyjne", $Z w, \mathrm{nr} 40,4.10 .1990,4$. 
Nie udało im się zrealizować postulatu o wzajemnym poparciu w wyborach samorzadowych (w maju 1990 r.), a Marian Krzaklewski zlikwidował Sekcję Kobiet „Solidarności”. Nadzieje na zmianę sytuacji kobiet dostrzegano w Kole Parlamentarnym Kobiet, założonym ponad podziałami partyjnymi w 1991 r. $z$ inicjatywy Barbary Labudy ${ }^{103}$. Podtrzymywano więc zainteresowanie kobiet ich rola w rządzeniu państwem. $Z$ jednej strony krytykowano postępujący marazm ruchów oddolnych, $z$ drugiej zaś strony podkreślano, że walką o władzę w sporach damsko-męskich zajmą się kobiety z elity ${ }^{104}$, „kobiety polityczne $z$ krwi i kości”, bo tylko one zdecydowały się „wejść do wyborczej gry”105. Warto wskazać, że częstym przedmiotem krytyki była Liga Kobiet Polskich. „Zwierciadło” będace jej organem prasowym starało się zmienić wizerunek organizacji, podkreślając jej rolę w walce o lepsze warunki pracy kobiet oraz poradnictwo $\mathrm{w}$ zarzadzaniu gospodarstwem domowym ${ }^{106}$.

Po trzecie, prasa dla kobiet kreowała u czytelniczek nawyk udziału w dyskusji publicznej. Zachęcano kobiety do formułowania opinii, prowokowano do przesyłania listów seria reportaży i wypowiedzi dotyczących form dyskryminacji kobiet w zakresie: 1) wynagrodzeń, 2) warunków pracy (chociażby w przemyśle lekkim), 3) awansu zawodowego, 4) wsparcia socjalnego, 5) zestawu cech idealnego polityka. Inicjowano działy, w których prezentowano wzmianki i komentarze na temat polityki. W „Przyjaciółce” były to: „Z kraju”, „Okno na świat”, „Fakty, Ciekawostki i Poglady”, „To Pani wybiera, Pani Kowalska”, „Popieramy”; w „Kobiecie i Życiu”: „Bariery awansu”, „Czas teraźniejszy”, „Czy demokracja jest rodzaju męskiego?”, „Nasza Dziesiątka”, „One nie zawioda”, „Pejzaż Polski”, „Rynkowe Lobby”, „Życie i Kobieta”, dyskusje: „O nas bez nas”, „Jeśli nie my, to kto?”; w „Zwierciadle”: „Chcemy o tym decydować”, „Twoje posłanki”.

Za priorytetowe uznano konsultacje na temat projektu ustawy o prawnej ochronie dziecka poczętego. Każde $z$ badanych pism zachęcało czytelników do przesyłania listów - do redakcji oraz do Sejmu.

\footnotetext{
${ }^{103}$ Iwona Konarska, „Pułapka”, 4-5; rozmowa Elżbiety Banasiak z Wiesławą Ziółkowską: „Dziś o tym, dlaczego potrzebne jest kobiece lobby”, Prz, nr 24, 13.06.1991, 2; Iwona Kołodziej, „Bez nas”, KiŻ, nr 7, 12.02.1992, 7.

${ }^{104}$ Iwona Konarska, „Pułapka”, 4-5.

${ }^{105}$ Rozmowa Natalii Iwaszkiewicz z Anną Popowicz: „Czy demokracja jest rodzaju męskiego?”, KiŻ, nr 45, 6.11.1991, 4.

${ }^{106}$ Krystyna Stachowicz, „Miejsce Ligi”, $Z w, n r$ 8, 23.02.1989, 7; eadem, „Ostatnia szansa”, $Z w, 22.02 .1990,2$.
} 
Wybrana korespondencję drukowano w specjalnych rubrykach (w „Kobiecie i Życiu” - „Ludzie listy pisza”, w „Przyjaciółce” - „Wasze listy”, „Bardzo "goracy" temat" oraz w dziale dyskusji „Sprawa przerywania ciąż”, w „Zwierciadle” - „Za i przeciw ustawie”, „Chcemy o tym decydować”) $)^{107}$. Postulowano o referendum w tej kwestii, wskazując, że „w pluralistycznym społeczeństwie prawo w razie braku w określonej sprawie consensusu, musi szukać rozwiązań kompromisowych"108.

Redakcje formułowały listy otwarte do przedstawicieli władz polskich, w tym m.in. do prezydenta Lecha Wałęsy, aby zobowiązał Sejm „(..) do ponownego rozpatrzenia ulg podatkowych dla osób samotnie wychowujących dzieci", do premiera, do ministra sprawiedliwości i Rzecznika Praw Obywatelskich w sprawie eksmisji mężczyzn znęcających się nad rodziną i waloryzacji alimentów ${ }^{109}$.

Po czwarte, przekonywano kobiety do współpracy zawodowej, społecznej i kulturalnej. W tym celu akcentowano sukcesy kobiet, które były wynikiem ich współdziałania $z$ innymi kobietami ${ }^{110}$. Na łamach „Przyjaciółki” informowano choćby o oddolnym ruchu młodych matek - nieformalnej Grupie Kobiet Wspierajacych Naturalne Karmienie ${ }^{111}$.

107 Vide np. „Ludzie listy piszą”: „Zabieg”, Ki்̇, nr 4, 25.01.1989,10-11; „Zabieg (2)”, KiŻ, nr 14, 5.04.1989, 10-11; „Piekło kobiet”, KiŻ, nr 44, 31.10.1990, 10-11. W rubryce „Wasze listy”: „W sprawie przerywania cią̇̇y”, $\operatorname{Prz}, \mathrm{nr} 19,11.05 .1989,7$; „O przerywaniu ciąży: przeciw, za...”, $Z w$, nr 2, 12.01.1989, 5; „Za i przeciw ustawie...”, $Z w$, nr 18, 4.05.1989, 4-5; „Za i przeciw ustawie...”, Zw, nr 19, 11.05.1989, 2; „Za i przeciw ustawie...”, Zw, nr 20, 18.05.1989, 6; „Chcemy o tym decydować”, $Z w$, nr 21, 25.05.1989, 4-5; „Chcemy o tym decydować”, $Z w$, nr 22, 1.06.1989, 4-5; „Chcemy o tym decydować, $Z w$, nr 24, 15.06.1989, 4-5; „Chcemy o tym decydować”, $Z w$, nr 28, 13.07.1989, 11; „Chcemy o tym decydować", $Z w$, nr 34, 7.09.1989, 4.

${ }^{108}$ Eleonora Zielińska, „Świat wobec aborcji”, KiŻ, nr 19, 10.05.1989, 12-13.

109 „Apelujemy do Lecha Wałęsy”, KiŻ, nr 47, 18.11.1992, 2; Zarząd Główny LKP, „List otwarty do Premiera”, $Z w$, nr 39, 12.10.1989, 2; Ruta Pragier, „Nie rosna tylko alimenty”, Prz, nr 13, 30.03.1989, 6; „Ludzie listy pisza””: „Wołanie o ratunek”, KiŻ, nr 11, 15.03.1989, 11; Ruta Pragier, „Adresat: Ministerstwo Sprawiedliwości: By prawo nie chroniło przestępcy", Prz, nr 36, 7.09.1989, 3.

110 mil., „Portfela i serca”, KiŻ, nr 46, 11.11.1992, 18; Agnieszka Metelska, „Spektroskop znaczy zdrowie”, KiŻ, nr 41, 25.10.1989, 13; Anna Brzozowska, „Sorores Optimae”, Ki்̇, nr 5, 30.01.1991, 3-4; Maria Machińska, „SOS w imieniu najsłabszych: Pomóżmy pomocy społecznej”, Prz, nr 39, 28.09.1989, 2-3; rozmowa Elżbiety Szczurowskiej z Marta Jenner: „Godność samotnych matek”, Prz, nr 37, 13.09.1990, 4-5; Ewa Grab, „Najlepsze z sióstr”, $Z w$, nr 10, 10.1991, 12; rozmowa Alicji Binskiej z przewodnicząca Ligi Kobiet Polskich Elżbietą Lęcznarowicz, 2; wywiad Iwony Konarskiej z Kingą Stawikowską, przewodnicząca Związku Kobiet i Dziewcząt Chrześcijańskich (YWCA), 23; Katarzyna Sieklucka, „Pomysł na siebie", Ki்̇, nr 48, 25.11.1992, 4-5.

${ }^{111}$ Alina Czerska, „Jak dobrze, że jesteście”, Prz, nr 6, 9.02.1989, 7. 
Przede wszystkim promowano w ten sposób inicjatywę powołania kobiecego lobby w różnych dziedzinach życia, np. w kinie czy przemyśle włókienniczym ${ }^{112}$. Uczono też solidarności kobiet, redakcja „Kobiety i Życia” zaproponowała czytelniczkom dział pt. „Nie daj się”, a „Przyjaciółki” „Jak żyć?”, w których oczekiwano na przesyłanie propozycji rozwiazywania „domowych kryzysów” (wynikających ze słabego zaopatrzenia rynku) czy sprawdzonych systemów organizacji prac domowych ${ }^{113}$. Przekonywano również do włączenia się w akcję recenzowania produktów, w tym celu w „Kobiecie i Życiu” zainicjowano w styczniu plebiscyt „Przebój Roku/ Bubel Roku 1989"114.

Po piąte, przekonywano czytelniczki do podejmowania wyzwań zawodowych i społecznych, ubiegania się o awanse. Łamiąc stereotyp o tradycyjnej roli kobiety, drukowano sylwetki tych, które osiagnęły sukcesy w różnych dziedzinach życia ${ }^{115}$. Redakcje „Przyjaciółki” i „Kobiety i Życia” objęły patronatem plebiscyt „Przedsiębiorczość w cenie”, w ramach którego publikowały sylwetki menadżerek odnoszacych sukcesy zawodowe ${ }^{116}$, „Zwierciadło” zaś ogłosiło konkurs „Dama Biznesu '91”117. W badanej prasie informowano o kobietach podejmujących inicjatywę gospodarcza, wdrażajacych kreatywne pomysły na biznes, samodzielnie przyswajających wiedzę ekonomiczną, zainteresowanych prywatyzacja przedsiębiorstw, w których dotychczas pracowały ${ }^{118}$. Tym samym po-

\footnotetext{
${ }^{112}$ Rozmowa Barbary Sass z Ilona Kondrat: „Damskie lobby”, KiŻ, nr 16, 19.04.1989, 9; „Rynkowe lobby”: Katarzyna Sieklucka, „Cienka nić, KiŻ, nr 36, 20.09.1989, 4.

${ }^{113}$ Ankieta „Kobiety i Życia”: „Nie daj się!”, KiŻ, nr 25, 21.06.1989, 16; „Jak żyć?”, Prz, nr 39, 28.09.1989.

114 „Wspólny plebiscyt "Atutu» i "Kobiety i Życia». Przebój Roku/Bubel Roku 1989”, KiŻ, $\mathrm{nr}$ 4, 25.01.1989, 5.

115 „Kobiety o których było głośno w 1989 r.”, KiŻ, nr 50, 27.12.1989, 5-7, 11-13, 15, 21; Joanna Czaj, „Przebudzenie?”, KiŻ, nr 22, 31.05.1989, 5; Mar., „Pierwsza”, Ki்̇, nr 23, 23.12.1992, 3; rozmowa Krystyny Stachowicz z prof. Jarosława Bauerowa: „O karierach kobiet”, Zw, nr 4, 26.01.1989, 5; rozmowa Barbary Adamczewskiej z Regina Smendzianka: „O sukcesie”, Zw, nr 10, 9.03.1989, 7; Elżbieta Bartczak, „Portret w srebrnej ramie”, Zw, nr 12, 23.03.1989, 2; Alina Gutek, „Gosia”, Zw, nr 1, 01.1992, 8-9.

${ }^{116}$ Natalia Iwaszkiewicz, „Przedsiębiorczość w cenie: Szefowa”, Ki்̇, nr 4, 25.01.1989, 3-4; Helena Kowalik, „Miękki kobiecy uścisk”, KiŻ, nr 33, 12.08.1992, 2; rozmowa Wiesławy Lipińskiej z Lilian Gotteff, dyrektor reklamy i marketingu francuskiej firmy DIM: „Kobiety chca mieć wszystko", $Z w$, nr 46, 30.11.1989, 4-5.

${ }_{117}$ Konkurs: „Dama Biznesu '91”, Zw, nr 10, 10.1991, 4; „Pierwsza dama biznesu”, Zw, nr 5, 05.1992, 26-28.

${ }^{118}$ Barbara Szczepuła, „Liberałki”, KiŻ, nr 48, 27.11.1991, 2-3; Grażyna Wróblewska, „Którędy do kapitalizmu?”, Ki̇̇, nr 3, 16.01.1991, 4; Kalina Gawęcka, „Załatwimy każdą sprawę...”, nr 14, 1.04.1992, 5; Barbara Ponikowska, „Młoda, ładna, dyspozycyjna”, KiŻ, nr 12, 18.03.1992, 4; Maria Machińska, „A jednak sa! Agencje jak grzyby po deszczu”, Prz,
} 
szukiwano remedium na rosnace wśród kobiet bezrobocie. Na łamach „Kobiety i Życia” Maria Mankiewicz prowadziła dział, w którym eksperymentowała $z$ inwestycjami, a następnie upowszechniała informacje, w jaki sposób można na nich zarobić ${ }^{119}$.

Aktywizacja społeczna i polityczna kobiet była warunkiem koniecznym do utrwalenia ich solidaryzmu i świadomości ich interesu grupowego $^{120}$, a w konsekwencji zwiększenia ich udziału w zarządzaniu państwem czy przedsiębiorstwem. Nie ograniczano się wyłącznie do promocji działań politycznych, gdyż dostrzegano niewielki wpływ kobiet na inne dziedziny życia, choćby gospodarkę państwa czy kulturę. Powstające organizacje kobiece zdawały sobie sprawę $z$ faktu, że priorytetem jest „uświadomienie kobietom, że nie sa ani gorsze, ani mniej atrakcyjne niż mężczyźni w zajmowaniu ważnych stanowisk w gospodarce, w polityce"121.

\section{Podsumowanie}

Analiza wybranych tytułów prasy dla kobiet w latach 1989-1992 pozwoliła na sformułowanie wniosku, że redakcje zmierzały do rozbudzenia aktywności kobiet. Nie ograniczały się do sfery polityki, choć ten aspekt dominował w prasie dla kobiet we wskazanym okresie. Wyraźnie przodowała w tym redakcja „Kobiety i Życia”, która konsekwentnie po pierwsze apelowała o włączenie się kobiet w debatę publiczna, po drugie prezentowała kandydatki do parlamentu nie tylko przed wyborami kontraktowymi (jak to było w przypadku „Przyjaciółki” i „Zwierciadła”), lecz również przed wyborami w 1991 r., po trzecie informowała o istotnych wydarzeniach w państwie i jako jedyna odniosła się do prac nad nowa konstytucja. Warto przywołać wypowiedź jednej z redaktorek „Kobiety i Życia" - Agnieszki Metelskiej, która w artykule na temat 45 lat funkcjonowania tygodnika wskazała, że jego mottem przewodnim sa słowa

\footnotetext{
nr 9, 2.03.1989, 5; Elżbieta Bartczak, „Life Modern czyli łatwiej, przyjemniej, rozumniej”, $Z w$, nr 39, 27.09.1990, 3.

${ }^{119}$ Maria Mankiewicz, „Ja, właścicielka dziurki od klucza”, KiŻ, nr 8, 20.02.1991, 2; eadem, „Jak robić pieniądze?”, KiŻ, nr 12, 20.03.1991, 5; eadem, „Ja, właścicielka dziurki od klucza”, Ki்̇, nr 23, 5.06.1991, 3; eadem, „Jeśli masz obligacje...”, KiŻ, nr 19, 6.05.1992, 4-5. ${ }^{120}$ Anna Titkow wskazała, że nie można pisać o interesie grupowym kobiet w sytuacji braku jego świadomości oraz braku solidaryzmu kobiet w dominującej kulturze patriarchalizmu. Zaproponowała zatem używanie terminu grup interesu kobiet, vide Anna Titkow, „Interes grupowy polskich kobiet”, 61.

${ }^{121}$ Rozmowa $z$ Danutą Waniek: „Ani gorsze, ani mniej atrakcyjne”, 4.
} 
Cypriana Kamila Norwida: „Jeżeli dzienniki sa potrzebne, to ażeby głosiły nie to tylko, co publiczność obchodzi, ale i co winno ja obchodzić $-z$ tego bowiem opinii moc urasta” ${ }^{22}$. Wyjątkowość dyskursu tygodnika „Kobieta i Życie" wynikała $z$ jasno sformułowanego celu u progu transformacji ustrojowej - zmiany pozycji kobiet w Polsce. Oczywiście „Przyjaciółka” i „Zwierciadło” również zabiegały o zmianę mentalności, jednakże proporcje wypowiedzi dotyczące polityki i innych sfer aktywności kobiet były wyrównane.

Reasumując, można stwierdzić, że redakcje prasy dla kobiet zabiegały o udział kobiet w systemie sprawowania władzy poprzez: 1) promocję pozytywnych wzorców kobiet, które połączyły życie prywatne $z$ zawodowym (nie podważano tradycyjnej roli kobiety w rodzinie), 2) zachęcanie czytelniczek do włączenia się w dyskusję o pozycji kobiet w Polsce (poprzez listy), 3) prezentacje godnych kandydatek na posłanki/senatorki oraz ministrów, 4) postulowanie o poparcie kobiet w wyborach (akcja „Głosuj na kobiety”) i umożliwienie współrządzenia kobiet i mężczyzn, a przede wszystkim decydowanie kobiet o sprawach dotyczacych ich bezpośrednio, 5) kampanie edukacyjne (zmiana świadomości społecznej na temat roli matki i żony), a przed wyborami - kampanie profrekwencyjne.

Badania pozwoliły jednak na wskazanie, że to nie transformacja ustrojowa zmobilizowała czytelniczki do dyskusji na łamach prasy, lecz projekt ustawy o prawnej ochronie dziecka poczętego. Dostrzegalny od 1990 r. był też spadek zainteresowania sprawami społecznymi i politycznymi ${ }^{123}$.

\section{Bibliografia}

\section{Akty prawne}

Ustawa $z$ dnia 27 kwietnia 1956 r. o warunkach dopuszczalności przerywania cią̇y, Dz. U. z 1956 r., nr 12, poz. 61.

Uchwała nr 172 (poz. 13) Rady Ministrów z dnia 29 października 1990 r. w sprawie zatwierdzenia planu zagospodarowania majątku Robotniczej Spółdzielczej Wydawniczej „Prasa-Książka-Ruch”.

\footnotetext{
${ }^{122}$ Agnieszka Metelska, „Nasza Rówieśnica”, 2-3.

${ }^{123}$ Vide więcej: Anna Szwed-Walczak, „Transformacja ustrojowa na łamach pisma "Kobieta i Życie»”, w: Małgorzata Dajnowicz, Adam Miodowski (red.), Polityka i politycy, 245-246.
} 


\section{Prasa}

Adamczewska, Barbara. „Kobiety w Sejmie i w Senacie”, Zwierciadło [dalej: $Z w]$, nr 27, 6.07.1989, 2.

(AMW), „Kobiety uderzyły pięścia w stół: chora przyszłość”, Przyjaciółka [dalej: Prz], nr 31, 1.08.1991, 5.

Ankieta „Kobiety i Życia”: „Nie daj się!”, Kobieta i Życie [dalej: KiŻ], nr 25, 21.06.1989, 16.

„Apelujemy do Lecha Wałęsy”, KiŻ, nr 47, 18.11.1992, 2.

Banasiak, Elżbieta. „Czas na działanie”, Prz, nr 27, 6.07.1989, 4.

Banasiak, Elżbieta. „Hyde Park po warszawsku”, Prz, nr 21, 25.05.1989, 5.

Banasiak, Elżbieta. „To Pani wybiera, Pani Kowalska”, Prz, nr 37, 12.09.1991, 4.

Banasiak, Elżbieta. „To Pani wybiera, Pani Kowalska: Oko w oko z kandydatem", Prz, nr 39, 26.09.1991, 4.

Banasiak, Elżbieta. „To Pani wybiera, Pani Kowalska: Wymagania "złotej główki»", Prz, nr 40, 3.10.1991, 4.

Banasiak, Elżbieta. „Wiosna w polskim parlamencie”, Prz, nr 14, 6.04.1989, 2.

„Bardzo "goracy" temat", Prz, nr 9, 28.02.1991, 6.

„Bardzo "goracy" temat”, Prz, nr 10, 7.03.1991, 6.

"Bardzo "goracy" temat”, Prz, nr 11, 14.03.1991, 4-5.

„Bardzo "goracy“ temat”, Prz, nr 12, 21.03.1991, 4-5.

Bartczak, Elżbieta. „Life Modern czyli łatwiej, przyjemniej, rozumniej”, Zw, nr 39, 27.09.1990, 3.

Bartczak, Elżbieta. „Portret w srebrnej ramie”, $Z w$, nr 12, 23.03.1989, 2.

Bierzańska, Danuta. „Ponad głowami”, KiŻ, nr 18, 2.05.1990, 4-5.

Bierzańska, Danuta. „Premier Tadeusz Mazowiecki: Polska będzie inna, jeśli zechca tego wszyscy”, KiŻ, nr 34, 6.09.1989, 4.

Bierzańska, Danuta. Oswaldo, Olga. „Goraczka demokracji”, Ki்̇, nr 22, 31.05.1989, 4.

Błaszczyk, Lidia. „Odpoczynek wojownika”, Ki̇̇, nr 21, 20.05.1992, 2.

Brzozowska, Anna. „Sorores Optimae”, KiŻ, nr 5, 30.01.1991, 3-4.

"Chcemy o tym decydować, $Z w, \mathrm{nr}$ 15, 20.04.1989, 2.

"Chcemy o tym decydować”, $Z w$, nr 21, 25.05.1989, 4-5.

„Chcemy o tym decydować”, $Z w$, nr 22, 1.06.1989, 4-5.

"Chcemy o tym decydować”, $Z w$, nr 24,15.06.1989, 4-5.

„Chcemy o tym decydować”, $Z w, \mathrm{nr} 28,13.07 .1989,11$. 
"Chcemy o tym decydować, $Z w$, nr 34, 7.09.1989, 4.

Cis, Anna. „Zadecyduja fakty”, KiŻ, nr 16, 19.04.1989, 5.

Czaj, Joanna. „Przebudzenie?”, KiŻ, nr 22, 31.05.1989, 5.

Czerska, Alina. „Jak dobrze, że jesteście”, Prz, nr 6, 9.02.1989, 7.

„Czy demokracja jest rodzaju męskiego", KiŻ, nr 14, 1.04.1992, 3.

„Czy demokracja jest rodzaju męskiego?”, KiŻ, nr 26, 24.06.1992, 6.

„Czy demokracja jest rodzaju męskiego: Gabinet nadal... do wzięcia”, Ki்̇, nr 26, 24.06.1992, 6.

Ede, Ika. „Pani Europa”, KiŻ, nr 48, 25.11.1992, 2.

E.W. „Zamach na tolerancje”, Zw, nr 23, 7.06.1990, 8-9.

„Europejka roku: Najlepsza wśród najlepszych”, KiŻ, nr 42,14.10.1992, 2-3.

Fra, „Jak głosujemy”, KiŻ, nr 22, 31.05.1989, 11.

Frankowska, Anna. „Brzemienne paragrafy”, KiŻ, nr 32, 8.08.1990, 4-5.

Frankowska, Anna. „Powrót do szaleństwa”, KiŻ, nr 23, 6.06.1990, 2.

„Gabinet do wzięcia”, Kï̇, nr 14, 1.04.1992, 8-9.

Gawęcka, Kalina. „Załatwimy każdą sprawę...”, nr 14, 1.04.1992, 5.

„Głosuj na kobiety”, Zw, nr 21, 25.05.1989, 2.

„Głosuj na kobiety”, $Z w$, nr 22, 1.06.1989, 8-9.

Grab, Ewa. „Najlepsze z sióstr”, Zw, nr 10, 10.1991, 12.

„Grozi nam przymus rodzenia”, Prz, nr 51, 17.12.1992, 4.

Gutek, Alina. „Gosia”, Zw, nr 1, 01.1992, 8-9.

Ika, „Dwa lata więzienia za przerwanie ciąży: Piekło - 1992”, Ki̇̇, nr 49, 2.12.1992, 2-3.

Iwaszkiewicz, Natalia. „Czy demokracja jest rodzaju męskiego? Na szczęście - NIE!: Premiera pani premier”, KiŻ, nr 31, 29.08.1992, 12-13.

Iwaszkiewicz, Natalia. „Przedsiębiorczość w cenie: Szefowa”, KiŻ, nr 4, 25.01.1989, 3-4.

„Jak będziemy wybierać prezydenta: Vademecum wyborcy”, Prz, nr 45, 8.11.1990, 4.

„Jak żyć?”, Prz, nr 39, 28.09.1989, 6-7.

„Jeśli nie my, to kto?”, Krystyna Kaszuba (oprac.), KiŻ, nr 20, 17.05,1989, 3.

K. G. M. „Bariery awansu: "Kury“ biurowe i naukowe”, KiŻ, nr 27, 5.07.1989, 2-3.

K.K-R. „Bolesna sprawa”, Prz, nr 23, 8.06.1989, 7.

„Kalendarium wyborcze (wg "Rzeczpospolitej«)”, Prz, nr 17, 26.04.1990, 4.

Kamińska, Zofia. „4220 dni Żelaznej Damy”, KiŻ, nr 3, 16.01.1991, 12-13. 
Kaszuba, Krystyna. „Za zamkniętymi drzwiami”, KiŻ, nr 4, 25.01.1989, 2. „Kobiety o których było głośno w 1989 r.”, KiŻ, nr 50, 27.12.1989, 5-7, $11-13,15,21$.

„Kobiety w Sejmie X kadencji i w Senacie”, Zw, nr 31, 3.08.1989, 5.

Kołodziej, Iwona. „Bez nas”, KiŻ, nr 7, 12.02.1992, 7.

Kołodziej, Iwona. „Bieda na jedwabiu”, KiŻ, nr 41, 9.10.1991, 2.

Komisja Porozumiewawcza Środowisk Kobiecych ds. Wyborów, „Głosuj na nas", Prz, nr 22, 1.06.1989, 4.

Komisja Porozumiewawcza Środowisk Kobiecych ds. Wyborów, „Głosuj na kobiety", Zw, nr 20, 18.05.1989, 5.

Konarska, Iwona. „Ciemności kryją kodeks”, KiŻ, nr 5, 29.01.1992, 2.

Konarska, Iwona. „Durna Blondynka”, Ki்̇, nr 18, 29.04.1992, 4.

Konarska, Iwona. „Dwa teatry”, KiŻ, nr 18, 29.04.1992, 2.

Konarska, Iwona. „Na granicy demokracji”, KiŻ, nr 42, 16.10.1991, 5, 15.

Konarska, Iwona. „Niemoralna”, KiŻ, nr 31, 29.07.1992, 2.

Konarska, Iwona. „Pułapka”, KiŻ, nr 39, 25.09.1991, 4-5.

Konarska, Iwona. „Wręczamy "Róg" po raz drugi”, KiŻ, nr 27, 1.07.1992, 15.

Konarska, Iwona. „Wybrać nie tylko wolność”, KiŻ, nr 43, 23.10.1991, 2-3.

Konarska, Iwona. „Życie poczęte chronić mają paragrafy. Na nic więcej nas nie stać. Czy to etyczne?”, KiŻ, nr 22, 27.05.1992, 2.

Konkurs: „Dama Biznesu '91”, Zw, nr 10, 10.1991, 4.

Kowalik, Helena. „Miękki kobiecy uścisk”, Ki்̇, nr 33, 12.08.1992, 2.

Kurczab-Redlich, Krystyna. „Ostatnia furtka”, Prz, nr 18, 4.05.1989, 6.

Limanowska, Barbara. „Dlaczego ogórek nie śpiewa”, KiŻ, nr 11, 15.03.1989, 2-3.

Ludzie listy piszą: „Piekło kobiet”, KiŻ, nr 44, 31.10.1990, 10-11.

Ludzie listy piszą: „Wołanie o ratunek”, KiŻ, nr 11, 15.03.1989, 11.

Ludzie listy piszą: „Zabieg”, KiŻ, nr 4, 25.01.1989, 10.

Ludzie listy pisza: „Zabieg (2)”, KiŻ, nr 14, 5.04.1989, 11.

Ludzie listy piszą: „Zejdźmy na ziemię”, KiŻ, nr 17, 24.04.1991, 10-11.

Łuszczuk, Ewa. „Wszystko co służy Polsce”, Prz, nr 20, 18.05.1989, 4.

(mm), „8 lipca zamiast 8 marca?”, $Z w, \mathrm{nr} 4$, 25.01.1990, 4.

Machińska, Maria. „A jednak sa! Agencje jak grzyby po deszczu”, Prz, nr 9, 2.03.1989, 5 .

Machińska, Maria. „SOS w imieniu najsłabszych: Pomóżmy pomocy społecznej”, Prz, nr 39, 28.09.1989, 2-3. 
Machnicki, Mieczysław. „Czy kobieta może być politykiem?”, $Z w, \mathrm{nr} 9$, 09.1991, 14-15.

Mankiewicz, Maria. „Ja, właścicielka dziurki od klucza”, KiŻ, nr 8, 20.02.1991, 2 .

Mankiewicz, Maria. „Ja właścicielka dziurki od klucza”, Kï, nr 23, 5.06.1991, 3.

Mankiewicz, Maria. „Jak robić pieniądze?”, KiŻ, nr 12, 20.03.1991, 5.

Mankiewicz, Maria. „Jeśli masz obligacje...”, KiŻ, nr 19, 6.05.1992, 4-5.

Mar., „Pierwsza”, Kï̇, nr 23, 23.12.1992, 3.

Metelska, Małgorzata. „Będę mówiła prawdę”, „KiŻ”, nr 14, 4.04.1990, 3-4.

Metelska, Agnieszka. „Droga do Belwederu”, Ki்̇, nr 47, 21.11.1990, 4-5.

Metelska, Agnieszka. „Nasza Rówieśnica”, KiŻ, nr 6, 6.02.1991, 2-3.

Metelska, Agnieszka. „Polki pokorne, Polki zbuntowane”, KiŻ, nr 50, 11.12.1991, 6-7.

Metelska, Agnieszka. „Spektroskop znaczy zdrowie”, KiŻ, nr 41, 25.10.1989, 13. mil., „Portfela i serca”, KiŻ, nr 46, 11.11.1992, 18.

Młynarczyk, Joanna. „Licytacja skończona”, KiŻ, nr 43, 23.10.1991, 2.

Musiałek, Grażyna. „Inauguracja”, Kï̇, nr 29, 19.07.1989, 2-3.

„Nad listami: Sterylizacja?”, KiŻ, nr 29, 18.07.1990, 11.

„Nasz Premier - Nasz Prezydent Tadeusz Mazowiecki”, Zw, nr 45, 8.11.1990, 3-4.

„Nasz prezydent”, KiŻ, nr 47, 21.11.1990, 11.

„Nasza "Dziesiątka». Zdaniem "Kobiety i Życia» - "One nie zawiodaı!", Ki்̇, nr 20, 17.05.1989, 13, 15.

„Nasza Europejka”, Prz, nr 50, 10.12.1992, 5.

„Nasze oczekiwania”, $Z w, \mathrm{nr}$ 12, 23.03.1989, 11.

Niepokulczycka, Małgorzata. „We wstecznym lusterku”, KiŻ, nr 26, 28.06.1989, 2.

Nowakowska, Ewa. „Kto płaci”, Zw, nr 10, 9.03.1989, 3.

„O narodzonych i nie narodzonych”, Prz, nr 27, 5.07.1990, 6.

„O nas bez nas”, nr 45, 22.11.1989, 5 .

"O nas bez nas (1)", Krystyna Kaszuba (oprac.), KiŻ, nr 13, 29.03.1989, 4-5.

„O nas bez nas (2)”, Krystyna Kaszuba (oprac.), KiŻ, nr 14, 5.04.1989, 2.

„O przerywaniu ciaży: przeciw, za...”, $Z w, \mathrm{nr} 2,12.01 .1989,5$.

„Od majowej do powstającej”, KiŻ, nr 18, 2.05.1990, 2.

„One nie zawioda”, KiŻ, nr 20, 17.05.1989, 4-5, 7, 12.

„One nie zawioda!", Ki்̇, nr 22, 31.05.1989, 2-3. 
„Oświadczenie”, Zw, nr 43, 9.09.1989, 5.

„Oświadczenie w sprawie projektu ustawy o ochronie prawnej dziecka poczętego", Prz, nr 43, 25.10.1990, 6.

„Oświadczenie Zarządu Głównego Towarzystwa Rozwoju Rodziny w sprawie projektu ustawy o prawnej ochronie dziecka poczętego", KiŻ, nr 27, 5.07.1989, 10 .

Piątek, Wiesława. „By wybierać dobrze”, Prz, nr 18, 4.05.1989, 4.

Piątek, Wiesława. „Na dobry początek”, Prz, nr 16, 28.04.1989, 4.

Piątek, Wiesława. „Nie zmarnujmy tej szansy!”, Prz, nr 8, 23.02.1989, 4.

Piątek, Wiesława. „Parlament w nowym kształcie”, Prz, nr 29, 20.07.1989, 4. „Piekło kobiet”, KiŻ, nr 16, 19.04.1989, 4.

„Pisane kobieca ręka. Listy, które w lutym i marcu br. nadeszły do uczestników Okragłego Stołu czytała i do druku podała Natalia Iwaszkiewicz", KiŻ, nr 15, 12.04.1989, 2-3.

Ponikowska, Barbara. „Młoda, ładna, dyspozycyjna”, Ki்̇, nr 12, 18.03.1992, 4. „Popieramy: Aleksandra Kwaśniewskiego, Stanisława Kwiatkowskiego, Leszka Millera, Dariusza Przywieczerskiego", Prz, nr 22, 1.06.1989, 5. „Popieramy Annę Szymańską-Kwiatkowska”, Prz, nr 22, 1.06.1989, 4. „Popieramy: Czesławę Górska, Andrzeja Bilika, Waldemara Zmaczyńskiego”, Prz, nr 21, 25.05.1989, 4.

„Popieramy: Elżbietę Lęcznarowicz, Marię Łopatkową, Małgorzatę Niepokulczycka, Alinę Tepli”, Prz, nr 22, 1.06.1989, 3.

(Prag.), „Raczkuje kobiece lobby”, Prz, nr 48, 29.11.1990, 5.

Pragier, Ruta. „Adresat: Ministerstwo Sprawiedliwości: By prawo nie chroniło przestępcy”, Prz, nr 36, 7.09.1989, 3.

Pragier, Ruta. „Kobieta, prawo i życie”, Prz, nr 28, 12.07.1990, 6.

Pragier, Ruta. „Nie rosna tylko alimenty”, Prz, nr 13, 30.03.1989, 11.

Pragier, Ruta. „To Pani wybiera, Pani Kowalska: Tylko dla dorosłych”, Prz, nr 38, 19.09.1991, 4.

Prezydium Demokratycznej Unii Kobiet, „Apel do kobiet polskich”, Prz, nr 32, 8.08.1991, 3.

Ratyńska, Janina. „Kara czy sumienie”, Prz, nr 15, 13.04.1989, 7.

Redakcja, „Przed wyborami do Sejmu i Senatu: przeczytaj, zastanów się, przedstaw swój pogląd", Prz, nr 19, 11.05.1989, 4.

„Remanent damskich spraw”, rozm. Elżbieta Banasiak, Prz, nr 4, 24.01.1991, 4-5. 
Rozmowa Alicji Bińskiej z przewodniczącą Ligi Kobiet Polskich Elżbietą Lęcznarowicz: „Blisko życia zwykłych ludzi”, KiŻ, nr 23, 7.06.1989, 2.

Rozmowa Barbary Adamczewskiej z Regina: „O sukcesie”, Zw, nr 10, 9.03.1989, 7.

Rozmowa Barbary Sass z Iloną Kondrat: „Damskie lobby”, Ki்̇, nr 16, 19.04.1989, 9.

Rozmowa Danuty Bierzańskiej z dr Danutą Waniek: „Niebezpieczna nieobecność”, KiŻ, nr 45, 22.11.1989, 5.

Rozmowa Danuty Bierzańskiej z prof. Anną Przecławską: „Koło Ratunkowe”, Kï̇, nr 9, 1.03.1989, 4-5.

Rozmowa Elżbiety Banasiak z Wiesławą Ziółkowską: „Dziś o tym, dlaczego potrzebne jest kobiece lobby", Prz, nr 24, 13.06.1991, 2.

Rozmowa Elżbiety Juszczak z senatorką z województwa koszalińskiego Gabrielą Cwojdzińską, KiŻ, nr 35, 13.09.1989, 4-5.

Rozmowa Elżbiety Szczurowskiej z Marta Jenner: „Godność samotnych matek", Prz, nr 37, 13.09.1990, 4-5.

Rozmowa Elżbiety Wierzbickiej z Jolantą Plakwicz i Anną Siwek, „Ruch którego nie ma?", $Z w$, nr 24, 15.06.1989, 3.

Rozmowa Grażyny Musiałek z Barbara Labuda, posłanka z Obywatelskiego Klubu Parlamentarnego: „Kwestia temperamentu”, Kï̇, nr 16, 18.04.1990, 2.

Rozmowa Krystyny Kaszuby z Jolantą Plakwicz: „Feminizm stowarzyszony”, KiŻ, nr 45, 22.11.1989, 5.

Rozmowa Krystyny Kaszuby z wicemarszałkiem Sejmu dr Olgą Krzyżanowska, „Sytuacja tworzy polityka”, KiŻ, nr 50, 27.12.1989, 2-3.

Rozmowa Krystyny Stachowicz z prof. Jarosława Bauerowa: „O karierach kobiet", $Z w, \mathrm{nr}$ 4, 26.01.1989, 5.

Rozmowa Marii Mankiewicz z Anną Popowicz: „Dywan z małych kawałków”, KiŻ, nr 18, 1.05.1991, 5.

Rozmowa Natalii Iwaszkiewicz z Anną Popowicz: „Czy demokracja jest rodzaju męskiego", Ki்̇, nr 45, 6.11.1991, 4.

Rozmowa Ruty Pragier z Danuta Waniek: „Dziś o tym, czy kobiety potrafia bronić swych praw", Prz, nr 15, 11.04.1991, 2.

Rozmowa Wiesławy Lipińskiej z Lilian Gotteff, dyrektor reklamy i marketingu francuskiej firmy DIM: „Kobiety chca mieć wszystko”, $Z w, \mathrm{nr} 46$, 30.11.1989, 4-5. 
Rozmowa Wiesławy Lipińskiej z prof. Arturem Bodnarem: „Budować od dołu", $Z w, \mathrm{nr}$ 6, 9.02.1989, 4.

Rozmowa z Danuta Waniek: „Ani gorsze, ani mniej atrakcyjne”, Zw, nr 40, 4.10.1990, 4.

Rozmowa Zygmunta Włoczewskiego z Małgorzatą Kielską-Żukowską: „Chcemy się rządzić sami”, Prz, nr 16, 19.04.1990, 5.

Rozmowa Zygmunta Włoczewskiego z prof. Anną Przecławską, Prz, nr 14, 6.04.1989, 5.

Sieklucka, Katarzyna. „Cienka nić”, KiŻ, nr 36, 20.09.1989, 4.

Sieklucka, Katarzyna. „Pomysł na siebie”, KiŻ, nr 48, 25.11.1992, 4-5.

Stachowicz, Krystyna. „Kobiety mówią NIE”, Zw, nr 11, 15.03.1990, 2-3.

Stachowicz, Krystyna. „Miejsce Ligi”, Zw, nr 8, 23.02.1989, 7.

Stachowicz, Krystyna. „Ostatnia szansa”, Zw, 22.02.1990, 2.

„Stanowisko Ligi Kobiet Polskich w sprawie dopuszczalności przerywania ciażzy", $Z w$, nr 18, 4.05.1989, 4-5.

„Stanowisko niezależnych ruchów kobiecych”, $Z w$, nr 20, 17.05.1990, 7.

Stolarska, Bożena. „Liczby o Polce”, Zw, nr 15, 20.04.1989, 6.

Szczepuła, Barbara. „Liberałki”, KiŻ, nr 48, 27.11.1991, 2-3.

Szymańska, Anna. Czas teraźniejszy: „Prezydent porozumienia”,KiŻ nr 31, 2.08.1989, 3.

Szymańska, Anna. „Ozdobnik”, KiŻ, nr 48, 13.12.1989, 3.

Szymańska-Kwiatkowska, Anna. „Czas nagli”, Kï̇, nr 28, 12.07.1989, 2-3.

„To Pani wybiera, Pani Kowalska: Co do ordynacji wyborczej warto wiedzieć”,

Ban. (oprac.), Prz, nr 41, 10.10.1991, 4.

„To Pani wybiera, Pani Kowalska: Co do ordynacji wyborczej warto wiedzieć

(2)", Ban. (oprac.), Prz, nr 42, 17.10.1991, 4.

„To Pani wybiera, Pani Kowalska: Co do ordynacji wyborczej warto wiedzieć

(3)", Ban. (oprac.), Prz, nr 43, 24.10.1991, 4.

Tepli, Alina. „Nie czuję się przegrana”, KiŻ, nr 28, 12.07.1989, 12.

Teresińska, Monika. „Bariery awansu: Polski schemat”, KiŻ, nr 34, 6.09.1989, 2. „Trzymamy za słowo”, KiŻ, nr 23, 7.06.1989, 4.

„Twoje posłanki”, $Z w, \mathrm{nr}$ 27, 6.07.1989, 2.

„Ty musisz wiedzieć, by mieć własne zdanie”, Prz, nr 25, 22.06.1989, 6-7.

„W sprawie ostatniej furtki”, Prz, nr 24, 15.06.1989, 7.

„W sprawie przerywania ciąży”, Prz, nr 19, 11.05.1989, 7. 
Wieczorkowska-Bednarek, Irma. „Prosto z Sejmu: "Gdy dwoje mówi to samo", KiŻ, nr 11, 14.03.1990, 11.

Wierzbicka, Elżbieta. „Między sumieniem a więzieniem”, $Z w, \mathrm{nr} 26$, 29.06.1989, 3.

Wierzbicka, Elżbieta. „Paskudna sprawa”, KiŻ, nr 43, 24.10.1990, 5, 22.

Wierzbicka, Elżbieta. „Przedwyborcza ściagaczka”, Zw, nr 19, 11.05.1989, 5.

Wierzbicka, Elżbieta. „Więcej niż dwie strony”, KiŻ, nr 8, 20.02.1991, 5.

Wierzbicka, Elżbieta. „Wybierasz dla siebie”, Zw, nr 20, 17.05.1990, 2-3.

Wierzbicka, Elżbieta. „Zaczyna się RUCH”, Zw, nr 47, 7.12.1989, 2-3.

„Wierzymy w kobietę. Czy demokracja jest rodzaju męskiego? Uparcie wołamy - NIE!", Ki்̇, nr 16, 15.04.1992, 8-9.

"Wokół projektu ustawy o ochronie życia poczętego: "Za i przeciw»", Prz, nr 32, 9.08.1990, 6 .

Wróblewska, Grażyna. „Którędy do kapitalizmu?”, KiŻ, nr 3, 16.01.1991, 4. „Wspólny plebiscyt "Atutu" i "Kobiety i Życia». Przebój Roku/Bubel Roku 1989”, KiŻ, nr 4, 25.01.1989, 5.

„Wybierzmy najlepszych”, Prz, nr 22, 1.06.1989, 4.

Wywiad Aliny Czerskiej z dr. Januszem Wojewódzkim: „To musisz wiedzieć”, Prz, nr 22, 31.05.1990, 6.

Wywiad Anny Sułkowskiej z Anną Szymańska-Kwiatkowską: „2000 razy kobieta", Prz, nr 41, 12.10.1989, 6-7.

Wywiad Elżbiety Wierzbickiej z Aliną Koźnińską: „Pro life”, KiŻ, nr 3, 16.01.1991, 4-5.

Wywiad Ewy Dobrowolskiej z Izabelą Nowacką z Ośrodka Dokumentacji i Informacji Naukowej przy Zarzadzie Głównym Ligi Kobiet Polskich: „Niech mama czegoś pragnie”, $Z w$, nr 10, 9.03.1989, 2.

Wywiad Grażyny Chlebowskiej z wicemarszałkiem Sejmu Olga Krzyżanowska: „Musi się udać”, Zw, nr 27, 5.07.1990, 3.

Wywiad Iwony Konarskiej z Barbarą Labudą: „Czarownice w Sejmie”, KiŻ, $\mathrm{nr}$ 40, 2.10.1991, 5 .

Wywiad Iwony Konarskiej z Kinga Stawikowska, przewodnicząca Zwiąku Kobiet i Dziewcząt Chrześcijańskich (YWCA): „Wywiad na zamówienie”, KiŻ, nr 6, 5.02.1992, 23.

Wywiad Kaliny Gawęckiej z Anną Mieszczanek: „Neutrum”, KiŻ, nr 3, 16.01.1991, 5. 
Wywiad Krystyny Kaszuby z Lidią Smyczyńska, naczelna „Tygodnika Demokratycznego", KiŻ, nr 18, 3.05.1989, 4.

Wywiad Marii Mankiewicz z Anną Popowską: „Czy kobieta Europy jest wśród nas?", KiŻ, nr 38, 16.09.1992, 2.

Wywiad Małgorzaty Bińkowskiej z Wandą Bogusławska: „Wywiad na zamówienie: Pigułka czy spirala?”, KiŻ, nr 1, 4.01.1989, 17.

Wywiad Natalii Iwaszkiewicz z Barbara Malak, rzecznikiem prasowym Komisji Krajowej NSZZ „Solidarność”, KiŻ, nr 33, 15.08.1990, 2-3.

Wywiad Renaty Marzewskiej z mgr Renatą Grabską: „Kobieta wytrzyma więcej”, KiŻ, nr 5, 1.02.1989, 2-3.

Wywiad Ruty Pragier z doc. Danutą Markowską: „Dziś o tym, czy w Polsce potrzebna jest partia kobiet”, Prz, nr 13, 29.03.1990, 2.

Wywiad Teresy Gałczyńskiej z Ewą Osiatyńską: „Wernisaż dusz”, KiŻ, nr 2, 11.01.1989, 17.

„Za i przeciw ustawie...”, $Z w$, nr 18, 4.05.1989, 4-5.

„Za i przeciw ustawie...”, $Z w, \mathrm{nr} 19,11.05 .1989,2$.

„Za i przeciew ustawie...”, Zw, nr 20, 18.05.1989, 6.

Załuski, Mariusz. „Kobieta też człowiek”, KiŻ, nr 44, 15.11.1989, 5.

„Zamach na tolerancje”, Zw, nr 25, 21.06.1990, 2-3.

Zarząd Główny LKP, „List otwarty do Premiera”, Zw, nr 39, 12.10.1989, 2.

Zielińska, Eleonora. „Świat wobec aborcji”, KiŻ, nr 19, 10.05.1989, 12-13.

Zubczewska, Zofia. „...A natura wie swoje”, KiŻ, nr 21, 22.05.1991, 2.

Zubczewska, Zofia. „Konsultacja”, KiŻ, nr 11, 13.03.1991, 3.

Zubczewska, Zofia. „Kto co mówi”, KiŻ, nr 16, 17.04.1991, 5.

Zubczewska, Zofia. „Wymyślony świat”, KiŻ, nr 6, 7.02.1990, 3-4.

Zubczewska, Zofia. „Zamiast wywiadu na zamówienie: "Lęki i żale»”, Kï̇, nr 18, 29.04.1992, 23.

„Źle strzeżona brama”, KiŻ, nr 14, 5.04.1989, 5.

\section{Opracowania:}

Bajka, Zbigniew. „Rynek mediów w Polsce”, w: Zbigniew Bauer, Edward Chudziński (red.), Dziennikarstwo i świat mediów, (Kraków : Universitas, 2004), 83-102.

Bignell, Jonathan. Media Semiotics. An Introduction, (Manchester : Manchester University Press, 2002). 
Boronowska, Magdalena. „Nowe szanse, ale czy nowoczesny sposób funkcjonowania współczesnej kobiety?”, w: Magdalena Baranowska-Szczepańska (red.), Ona w XXI wieku - interdyscyplinarny obraz kobiety, (Poznań : Instytut Naukowo-Wydawniczy Maiuscula, 2011), 134-165.

Dajnowicz Małgorzata, „Posłanki Ligi Kobiet Polskich i wybory parlamentarne 1989 roku (prezentacja w świetle „Zwierciadła”)”, w: Małgorzata Dajnowicz, Adam Miodowski (red.), Polityka i politycy w prasie XX i XXI wieku: polityka w prasie kobiecej, (Białystok : Wydawnictwo Uniwersytetu w Białymstoku, 2019), 205-215.

Dajnowicz, Małgorzata. "Zwierciadło" - platforma polityczna Ligi Kobiet w okresie PRL (1957-1961, 1982-1989)", Rocznik Historii Prasy Polskiej, t. 3, 2017, 72-74.

Dąbrowska-Cendrowska, Olga. „Dwadzieścia lat minęło. Działalność wydawnicza koncernów: Burda Polska, H. Bauer, Gruner+Jahr Polska i Axel Springer Polska na polskim rynku prasowym", Studia Medioznawcze, $\mathrm{nr}$ 2, 2010, 90-106.

Dziki, Sylwester. „Zmiany oferty prasowo-wydawniczej (1990-1991)”, Zeszyty Prasoznawcze, nr 3-4, 1991, 67-90.

Filas, Ryszard. „Zmiany poczytności gazet i czasopism o zasięgu ogólnopolskim (1989-1992)", Zeszyty Prasoznawcze, nr 1-2, 1992, 55-74.

Fuszara, Małgorzata. „Zmiana w świadomości kobiet w Polsce w latach dziewięćdziesiątych", w: Małgorzata Fuszara (red.), Kobiety w Polsce na przełomie wieków. Nowy kontrakt płci?, (Warszawa : Instytut Spraw Publicznych, 2002), 13-38.

Hajdo, Małgorzata. „Wizerunek kobiety jako matki, pracownika i działaczki społecznej prezentowany na łamach prasy kobiecej w latach 1948-1956", Dzieje Najnowsze, R. XXXVIII, 2006, 55-72.

Jarowiecki, Jerzy. Studia nad prasa polska XIX i XX wieku, (Kraków : Wydawnictwo Naukowe WSP, 1997).

Kłoskowska, Antonina. „Modele społeczne i kultura masowa”, Przeglad Socjologiczny, nr 13(2), 1959, 46-71.

Mielczarek, Tomasz. „Pożegnanie z prasa. Czy w Polsce kończy się era Gutenberga?", Zeszyty Prasoznawcze, nr 1-2, 2007, 51-68.

Mielczarek, Tomasz. „Współczesne polskie czasopisma wysokonakładowe”, Rocznik Prasoznawczy, R. II, 2008, 57-79. 
Pepliński, Wiktor. „350 lat historii prasy w Polsce (spojrzenie na jej przeszłość i teraźniejszość)", Studia Medioznawcze, nr 2, 2011, 25-39.

Pisarek, Walery. O mediach i języku, (Kraków : Universitas, 2007).

Sokół, Zofia. „Przyjaciółka" - tygodnik kobiecy. (Część II: marzec 1951 - marzec 1990)", Studia Bibliologiczne Akademii Świętokrzyskiej, t. 7, 2003, 109-131.

Sokół, Zofia. „Transformacja czasopism kobiecych w Polsce (1989-1997)”, Rocznik Historii Prasy Polskiej, z. 2, 1998, 193-201.

Sokół, Zofia. „Wizerunki kobiet na łamach tygodnika "Kobieta i Życie" w latach 1946-2002", Rocznik Prasoznawczy, R. VI, 2012, 11-36.

Sonczyk, Wiesław. „Kolportaż prasy w Polsce do roku 1989”, Studia Medioznawcze, nr 2, 2010, 80-89.

Szot, Lucyna. „Wpływ profesjonalizmu dziennikarzy na transformacje polskiej prasy po 1989 roku", Studia Medioznawcze, nr 2, 2010, 27-38.

Szwed-Walczak, Anna. „Obraz wyborów kontraktowych w Polsce na łamach prasy dla kobiet”, Czasopismo Naukowe Instytutu Studiów Kobiecych, nr 1, 2019, 151-173.

Szwed-Walczak, Anna. „Transformacja ustrojowa na łamach pisma "Kobieta i Życie"”, w: Małgorzata Dajnowicz, Adam Miodowski (red.), Polityka i politycy w prasie XX i XXI wieku: polityka w prasie kobiecej, (Białystok: Wydawnictwo Uniwersytetu w Białymstoku, 2019), 231-246.

Tetelowska, Irena. „Analiza zawartości gazet - wstępne stadium funkcjonalnej typologii prasy", Zeszyty Prasoznawcze, nr 4, 1962, 3-19.

Titkow, Anna. „Interes grupowy polskich kobiet”, w: Małgorzata Fuszara (red.), Kobiety $w$ Polsce na przełomie wieków. Nowy kontrakt płci?, (Warszawa : Instytut Spraw Publicznych, 2002), 39-64.

Zajko-Czochańska, Justyna. „Monografia "Przyjaciółki» - zarys zagadnienia”, Niepodległość i Pamięć, nr 2, 2019, 213-226. 